\title{
Early to lowermost Middle Triassic Foraminifera from the Locker Shale of Hampton-1 well, Western Australia
}

\author{
M. APTHORPE \\ School of Earth \& Geographical Sciences, The University of Western Australia, 35 Stirling Highway, Crawley WA 6009, Australia \\ (e-mail: aptpal@ozemail.com.au)
}

\begin{abstract}
Marine smaller foraminifera from a $350 \mathrm{~m}$ thick, non-carbonate borehole succession are described from the upper Lower Triassic to lowermost Middle Triassic (Spathian-Lower Anisian) of offshore Western Australia. This is only the second foraminiferal fauna of this age described from the Southern Hemisphere and it differs from a coeval fauna previously described from the same area (Heath \& Apthorpe, 1986). The new fauna contains some 'Tethyan' genera previously recorded from South China and the Alps, including Duostomina, Krikoumbilica, Gsollbergella, Trocholina, Endothyra and Endothyranella. Other genera and species appear to persist from the Permian. Three species are described as new: Dentalina septacosta, Krikoumbilica compressa and Trocholina planoconvexa. The age of the fauna is based on palynological evidence, correlated with conodont dating. J. Micropalaeontol. 22(1): 1-27, July 2003.
\end{abstract}

\section{INTRODUCTION}

Marine microfaunas of Early and Middle Triassic age are poorly known in Australia, as marine sedimentation during the Triassic was largely confined to offshore areas on the northwestern margin of the continent. During the Early Triassic a shallow sea occupied areas along the western margin of Australia which subsequently developed into the Bonaparte, Canning, Carnarvon and Perth Basins (Fig. 1). Predominantly fine-grained clastic units deposited at this time include the Mt Goodwin Formation in the Bonaparte Basin, the brackish Blina Shale of the Canning Basin, the predominantly marine Locker Shale of the Carnarvon Basin and the marine Kockatea Shale of the Perth Basin.

This shallow Triassic sea occupied part of the continental shelf of Eastern Gondwana, on the southern margin of eastern Tethys (Ogg \& von Rad, 1994). According to their reconstructions, the location studied here, within the later-formed Carnarvon Basin (Fig. 1), was at a temperate palaeolatitude of $50^{\circ} \mathrm{S}$ during the Early Triassic, warming to a palaeolatitude of $40^{\circ} \mathrm{S}$ during the Middle Triassic, as a result of plate movements. The area lies southeast of the Exmouth Plateau and at least $700 \mathrm{~km}$ southeast of the inferred margin of the deep Tethys Ocean (Ramsay \& Exon, 1994), indicating the great width of the marginal sea at this time.

In the Carnarvon Basin, the Early Triassic transgression commenced with variable sands, shales and, near the base, two limestones (Fig. 2; Hocking et al., 1987; Gorter, 1994). The limestones have been given formation status, as the (basal) Sholl Formation, and the stratigraphically younger Cunaloo Formation, by Gorter (1994). The Lower to basal Middle Triassic marine succession is referred to as the Locker Shale (Parry, in Jones, 1967), although the lithology varies from shale, through siltstone, to fine sandstone in some wells.

The Locker Shale occurs only in the subsurface and has been studied in some petroleum exploration wells (McTavish, 1973; Gorter, 1994). Over much of the Carnarvon Basin this Lower to Middle Triassic marine succession has been deeply buried beneath thick Jurassic and Upper Triassic marine and fluviodeltaic strata, and is beyond the reach of commercial exploration drilling. Along the eastern margin of the basin, however, the Lower to Middle Triassic is present at shallow to moderate depths in a series of tilted fault blocks, some of which have been drilled by petroleum exploration wells. The foraminifera from the Hampton-1 well, drilled in 1974, are described here (BOC of Australia Ltd, 1974).

\section{AGE AND CORRELATION OF THE STUDIED SUCCESSION}

The overall age of the Locker Shale has been established from conodont studies (McTavish, 1973; Gorter, 1994) and palynology (Balme, 1969; Helby et al., 1987) in wells including Cunaloo-1 and Sahul Shoals-1 (Fig. 1). The age of both the top and base of the formation varies. The oldest dating is Dienerian (Neospathodus dieneri conodont zone) (Gorter, 1994, quoting McTavish, 1973). This is some 3.5 million years above the base of the Triassic, according to the time-scale of Haq et al. (1987, 1988). The youngest dating ascribed to most of the top of the Locker Shale is Anisian or, in some wells, Ladinian. The framework for the palynological zonations customarily used to date Australian Triassic sequences is outlined in Balme (1990). Whilst the two Lower Triassic palynological zones are fairly well constrained by isolated conodont dates, the Middle Triassic zones are not (see Fig. 2).

Foraminifera have been described previously from the Locker Shale: a large and well-preserved fauna, believed at that time to be of Anisian age, was described from Lawley-1 well (Heath \& Apthorpe, 1986). The faunas described in this paper come from the petroleum exploration well Hampton-1, located at $20^{\circ} 7^{\prime} 4^{\prime \prime} \mathrm{S}$ $116^{\circ} 32^{\prime} 47^{\prime \prime} \mathrm{E}$, drilled in 1974 by BOC of Australia Ltd, $54 \mathrm{~km}$ to the southwest of Lawley-1. Almost all the Locker Shale in Hampton-1 falls within the Triplexisporites playfordii palynological zone (Figs 2 and 3), which is divided into an 'upper' and an 'undifferentiated' interval (R. J. Helby, unpublished data). A horizon within the upper part of the zone is dated as latest Spathian to very early Anisian, based on the presence of the conodont Chiosella timorensis timorensis at $635.1 \mathrm{~m}$ in the upper part of this zone in Lawley-1 well (Gorter, 1994; Nicoll \& Foster, 1998). The Triplexisporites playfordii zone as a whole had earlier been dated on conodont evidence as extending from the Smithian to possibly the earliest Anisian (McTavish, 1973). The uppermost 
M. Apthorpe

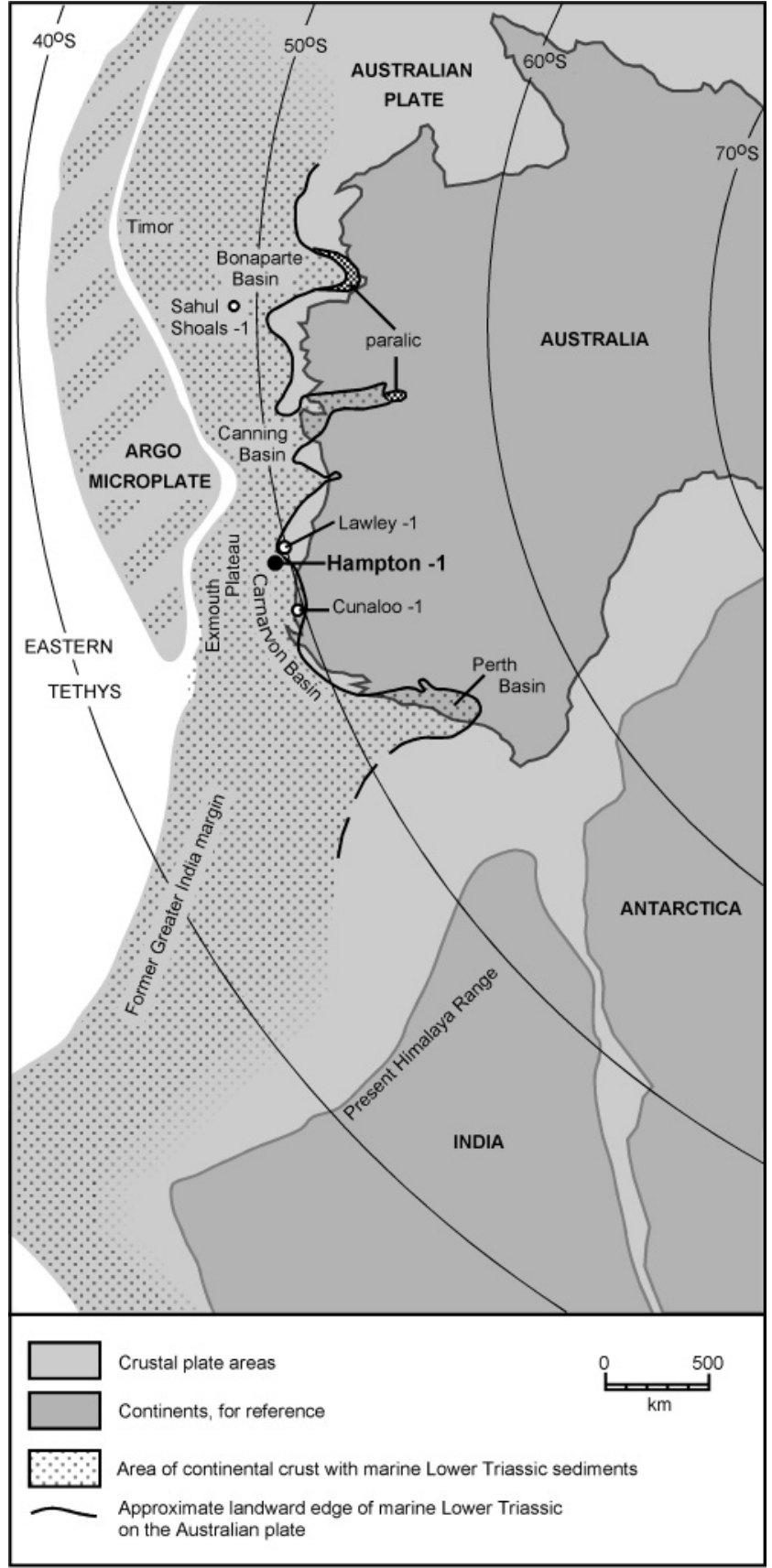

Fig. 1. Location map and regional setting of Hampton-1 and Lawley-1 wells, marginal Australian basins, and Eastern Gondwana continental plates. Also shown are other key wells in the Triassic stratigraphy of Western Australia (see Gorter, 1994). Base map and palaeolatitudes for the Early Triassic from Ogg \& von Rad (1994, fig. 3). Triassic coastline of Australia modified from BMR Palaeogeographic Group (1990). Note that the outline and extent of marine facies on the Argo Microplate are unknown.

part of the Locker Shale in Hampton-1 is dated as the Staurosaccites quadrifidus palynological zone, which is ascribed a late Anisian to Ladinian age, based on the presence of the dinoflagellate Sahulidinium ottii in its upper part (Helby et al., 1987). Gorter (1994) placed the top of the T. playfordii zone and the base of the $S$. quadrifidus zone within a single seismo-stratigraphic sequence.

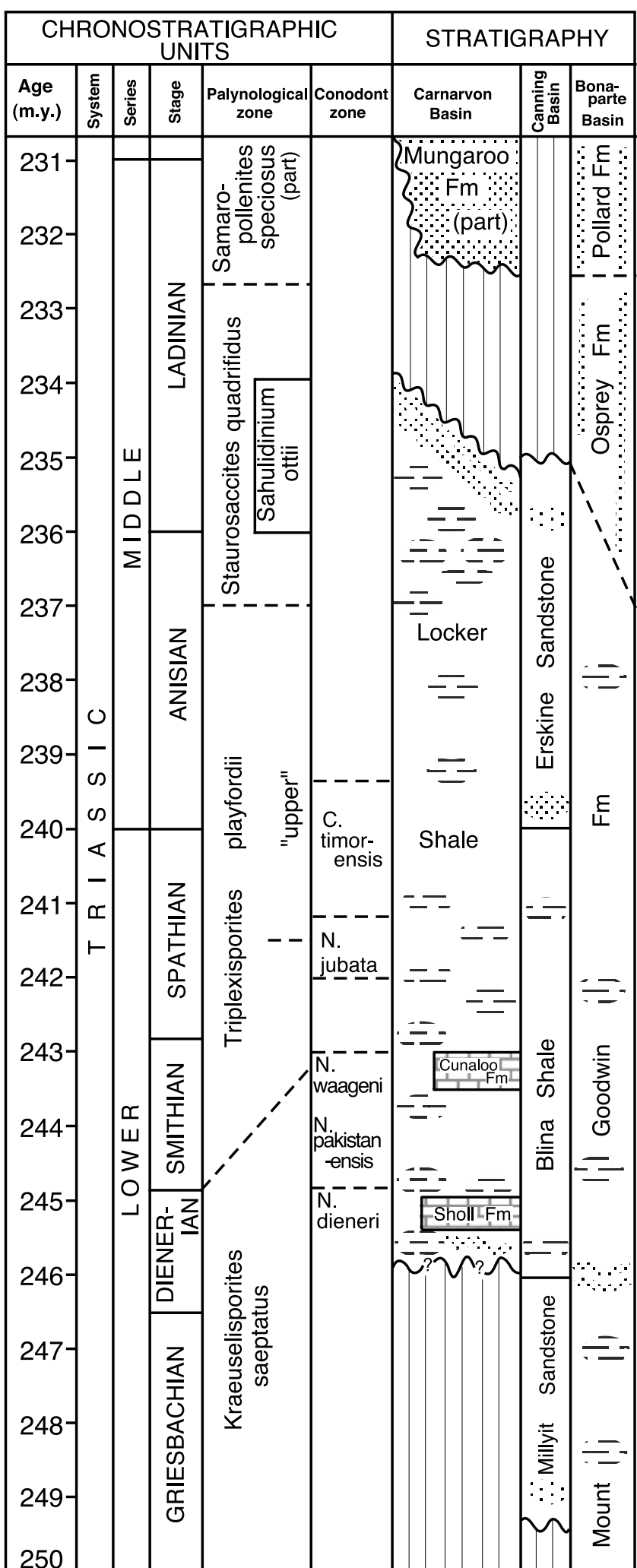

Fig. 2. Stratigraphy of some Lower to Middle Triassic successions, northwestern Australian margin. Palynological zonation after Helby et al. (1987) and Balme (1990); conodont zonation after Nicoll \& Foster (1998); Carnarvon Basin stratigraphy partly after Gorter (1994); Bonaparte Basin stratigraphy after Gorter et al. (1998). 


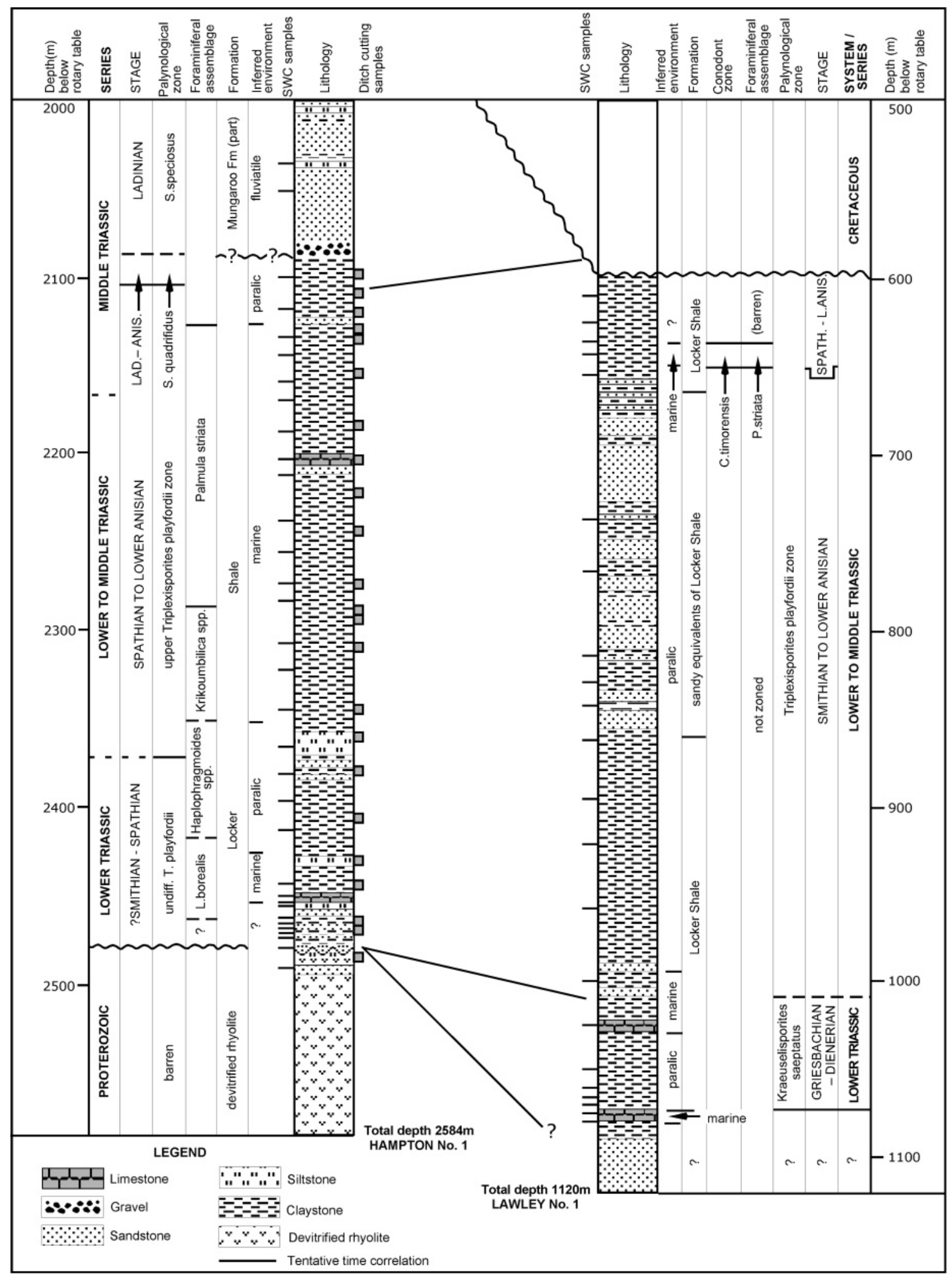

Fig. 3. Locker Shale sequence in Hampton-1 well and Lawley-1 well, showing sample locations, palynological age determinations, foraminiferal assemblages and interpreted depositional environments. 
The Hampton-1 well contains $460 \mathrm{~m}$ of Locker Shale, of which $365 \mathrm{~m}$ are foraminifera bearing. From the palynological and conodont evidence outlined above, it appears that the foraminiferal succession may span the Spathian and at least part of the early Anisian. The highest foraminiferal samples occur just below the apparently conformable contact between the playfordii and quadrifidus zones.

\section{MATERIAL EXAMINED}

All of the 26 samples picked for foraminifera, with the exception of the sidewall core at $2169 \mathrm{~m}$ were, of necessity, ditch cuttings (see Fig. 3). The original quantities of sample processed are not recorded, but were probably approximately $15 \mathrm{~g}$. The samples were processed by soaking in dilute hydrogen peroxide, then washing over a $63 \mu \mathrm{m}$ sieve, which resulted in processed sample weights of 4-10 g. Variable quantities of processed samples were completely picked. By dividing the number of specimens recovered by the weight of sample picked, a rough estimate of sample yield has been obtained. The sample yield is diluted by interbedded sands between $2180 \mathrm{~m}$ and $2205 \mathrm{~m}$, where only c. 25 specimens were found per gram of processed sediment picked. Richer intervals of calcareous shale and siltstone between $2125 \mathrm{~m}$ and $2155 \mathrm{~m}$ yielded 60 to 160 specimens per gram of washed residue. The sidewall core sample at $2169 \mathrm{~m}$ is a muddy fine-grained coquina of molluscan, algal and other fragments with common foraminifera, and the original weight of sample processed is recorded. It contains the maximum number of foraminifera found, 774 specimens per gram of residue, which equates to 380 foraminifera per gram within the original unprocessed sediment. In contrast, the deepest samples between $2440 \mathrm{~m}$ and $2485 \mathrm{~m}$ are hard carbonaceous micaceous shales, yielding some molluscs and algal fragments, but few foraminifera $(<1$ to 9 specimens per gram of processed sample residue). In part the low foraminiferal yields may be due to poor breakdown of the samples, but examination of many rock fragments suggests that the foraminiferal numbers are diluted by higher sedimentation rates and possibly unfavourable conditions. Interbedded thin white limestones at 2460-2465 m, with associated foraminifera, raise the yield slightly over this interval.

In comparison with Cretaceous to Cenozoic assemblages in the region, the Triassic foraminiferal yield in Hampton-1 well is sparse to rare. The quality of ditch cuttings is, however, surprisingly good. Although the Triassic Locker Shale and Mungaroo Formations are overlain by Jurassic sediments and a thin Cretaceous interval, caving of fauna from these levels is virtually non-existent. The Locker Shale Triassic fauna varies in preservation type from sample to sample, and is always correlatable with the numerous variations in lithology, from calcareous claystone to sandy siltstone. From this it is thought that the sample depths given fairly accurately reflect the microfaunal succession. Some caving of coarser quartz sand from the overlying Late Triassic Mungaroo Formation is present in most samples. However, this fluviatile formation does not contain foraminifera in Hampton-1.

\section{THE FORAMINIFERAL SUCCESSION AND INTERPRETED PALAEOENVIRONMENTS}

The succession has been subdivided into informal assemblages (Fig. 3). The highest assemblage between $2125 \mathrm{~m}$ and $2290 \mathrm{~m}$ contains the greatest number of specimens and species. The lithologies vary from sample to sample, from shale to calcareous siltstone and silty sandstone. The richest sample is the sidewall core at $2169 \mathrm{~m}$, a calcareous silty claystone with an abundance of thin-shelled ostracod fragments and other molluscs in layers parallel to the bedding. The foraminifera are less numerous, but still common. Specimen sizes, as throughout the succession, are relatively small, possibly reflecting the temperate sea temperatures. Many specimens (including those from the sidewall core at $2169 \mathrm{~m}$ ) are broken, suggesting current activity or transportation of specimens. The assemblage (here named the Palmula striata assemblage) is correlated with the abundant but Lingulina-dominated foraminiferal horizon in Lawley-1 well at $635.1 \mathrm{~m}$. The latter is thought to be an estuarine or embayment assemblage, based on the total dominance $(>90 \%)$ of one species, and the absence of foraminifera in samples above and below. Hocking et al. (1987, fig. 76) interpret the Early Triassic coastline to have been bounded by tidal flats and a series of barrier bars near river mouths, partly enclosing bays, based on sedimentological evidence in twelve wells. The Hampton-1 assemblages are more poorly preserved and are lower in specimen numbers in comparison with the single assemblage at Lawley-1. They are interpreted to have been deposited on an open marine shelf, based on the relatively large number of species present. Other fossil groups present (echinoderm fragments, crinoid ossicles, tiny brachiopods, gastropods, ostracods, bivalve fragments and algal fragments) appear to confirm such an interpretation.

The second assemblage in Hampton-1 occurs between $2290 \mathrm{~m}$ and $2345 \mathrm{~m}$. Samples are dominated either by Krikoumbilica spp., or by Lingulina borealis. Other genera are fewer in number than above. The lithology consists of light grey shales, and fine calcareous sandstones, the latter rich in thin-shelled ostracods and ostracod fragments. In one sample some of the shale fragments are ferruginized. Either shallower marine water depths, or a more restricted marine circulation, is interpreted for this interval, based on the lower specimen numbers, and higher dominance of one species in these samples.

The third assemblage, between $2355 \mathrm{~m}$ and $2405 \mathrm{~m}$, contains rare specimens of the siliceous agglutinated Haplophragmoides sp. A and sp. B as virtually the only species present. Some shale fragments are rich in mica and there is subordinate sandstone present. The interval is interpreted as a paralic environment, possibly with some influx of fresh water from local rivers, based on analogies with the Early Cretaceous of the Great Australian Basin (Haig, 1979a, 1980). Similar, even more impoverished assemblages were found in the well Lawley-1 (Fig. 3) where three shale cores between $894 \mathrm{~m}$ and $957 \mathrm{~m}$ contain assemblages of two species of Haplophragmoides, plus Ammobaculites, with megaspores at $957 \mathrm{~m}$. The Lawley-1 sequence is considerably sandier than Hampton-1, and some shale sidewall cores contain coarse-grained frosted quartz, suggestive of nearby beach or dune environments; whilst others are micaceous, and entirely barren of calcareous fossils. The environmental interpretation of Haplophragmoides is further discussed below.

The fourth assemblage, present between $2425 \mathrm{~m}$ and $2465 \mathrm{~m}$, is a mixed one consisting of Haplophragmoides, preserved in a claystone matrix, thin-shelled molluscs, and a scattering of calcareous species in low numbers, principally Lingulina 
borealis, preserved in a more calcareous matrix. The interval is thought to consist of interbedded brackish paralic claystones, alternating with thin shallow-marine or estuarine limestones, as the well lies near the landward edge of marine Triassic deposition. Such lithological and faunal alternations may well have resulted from fluctuating salinity in a marine embayment, intermittently closed off from the open sea.

The interpretation of a paralic environment for assemblages consisting largely or entirely of Haplophragmoides (with Ammobaculites in some samples) is not in agreement with the depiction of Haplophragmoides as a predominantly deep-water taxon, which is found in literature on the Jurassic (e.g. Gradstein, 1983, table 3). However, Nagy (1992, fig. 11) indicates its presence in low numbers in pro-delta environments in the Jurassic of the North Sea. Haplophragmoides is not a taxon that has been mentioned in previous studies of Triassic environments. This is probably because most Triassic studies have involved study of the foraminifera in low-latitude carbonate associations. The apparent migration of the genus into deeper water during the mid-Tertiary obscures its palaeoenvironmental significance in high-latitude Mesozoic assemblages. Amongst Mesozoic assemblages, the following offer support for a shallow, cool-water, probably hyposaline interpretation for the very low diversity Triassic Haplophragmoides assemblages seen in Hampton-1.

The siliceous-walled Haplophragmoides is a common component of the Lower Cretaceous shallow epicontinental Ammobaculites Association in Australia (Haig, 1979b, 1980). Haig interprets the controlling factors to include shallow, land-locked seas at palaeolatitudes higher than $30^{\circ} \mathrm{N}$ and $\mathrm{S}$, with cool water temperatures and lower than normal salinities from freshwater influx, leading to dissolution of calcium carbonate. Haplophragmoides is also a common genus (and sometimes the only foraminiferid present) in Upper Cretaceous faunas in the cold temperate Otway Basin, a narrow elongated rift basin with limited marine connections, in a wet climate, located at a palaeolatitude of $70^{\circ} \mathrm{S}$ (Taylor, 1964). In the Upper Cretaceous and Upper Albian of western Canada, Haplophragmoides is common to abundant in diverse agglutinated assemblages which are almost totally lacking in calcareous Foraminifera (Stelck \& Koke, 1987). Water-depth interpretations of such assemblages have varied in detail between various authors (e.g., Wall, 1960; Stelck, 1975; Stelck \& Koke, 1987; Stelck \& Leckie, 1988, 1990; Stelck, 1991) with Haplophragmoides present in assemblages interpreted as ranging from littoral, to marine shelf less than $200 \mathrm{~m}$ deep. Common elements are the dominance of Haplophragmoides in the shallowest facies $(<20 \mathrm{~m}$ interpreted water depth), the cool temperate nature of the assemblages, the possible dissolution of any calcareous species originally present, due to lowered $\mathrm{pH}$, and the suggestion of turbidity in the mud-dominated environment. Whereas the older papers listed above mention the present occurrence of Haplophragmoides in water depths greater than $200 \mathrm{~m}$, the later papers avoid reference to such Recent analogues, and are more tentative in their suggestions of water depth, reflecting the difficulty of using modern distributions as a key to the Mesozoic.

\section{PALAEOGEOGRAPHY}

The foraminiferal assemblages described here from Hampton-1 well are diverse, comprising some 80 species, and they contain a number of species and genera previously described from Tethyan areas. The previously described Lawley-1 assemblages (Heath \& Apthorpe, 1986) are dominated (>90\%) by Lingulina borealis, described from Alaska. The differences between the faunal composition of the Lawley and Hampton assemblages suggest, not an age difference, nor a division into 'Boreal' and 'Tethyan' over a distance of some $50 \mathrm{~km}$, but simply a facies difference between the wells, as mentioned in the previous section. Whereas the upper part of the Hampton section is believed to represent a marine shelf facies, Lawley contains a thin interval of extremely abundant foraminifera which is interpreted to represent an estuarine or embayment environment, in the middle of an otherwise paralic or coastal sequence. The latter contains only the genera Haplophragmoides and Ammobaculites which occur sporadically, interspersed with barren samples containing indications of coastal environments, and sand intervals.

\section{COMPARISON WITH ANISIAN ASSEMBLAGES FROM OTHER REGIONS}

The Hampton-1 foraminiferal assemblages are mostly dissimilar in species and generic composition to assemblages of Anisian age reported in the literature from other regions of the world. The closest comparisons are with some assemblages from South China and Iran, and possibly with assemblages from Poland.

Kristan-Tollmann (1983) gives a comprehensive description of an Anisian fauna from the Leidapo Member of the Qingyan Formation of South China. The fauna is dominated by Duostominidae, including Diplotremina spp., Duostomina spp. and Variostoma sp. Of these, only Duostomina occurs in the Hampton assemblage, in very small numbers. Of the 63 species in the Leidapo assemblage, only five occur in the Hampton-1 assemblage of 80 species. The most common species in the Hampton-1 assemblage (Lingulina borealis and Krikoumbilica spp.) are not listed in the Leidapo assemblage (although Polytaxis? leidapoensis Kristan-Tollmann may possibly be a Krikoumbilica).

From the same formation in South China, He (1984) describes foraminifera from the Anisian 'reef-facies' of the Qingyan Formation. This assemblage is reported to consist of 'Meandrospira dinarica, Glomospira densa, Glomospirella grandis, etc.'. None of these is present in Hampton-1. From the Yongningzhen Formation in Baiceng, Zhenfeng County, He records the Anisian fauna as Diplotremina stenocamera, Endothyra badouxi and Pseudolituonella? sp., none of which have been found in Hampton-1. From the reef-facies of the Yanglinjong Formation, Baiceng, Zhenfeng County, He records Trocholina (three species) and Turritellella mesotriasica. Trocholina (two species) occur in Hampton-1 but are extremely rare. At another locality within the same formation, He records the presence of Krikoumbilica pileiformis, a species which is common in part of the Hampton-1 sequence. At a locality in the Zhuganpo Formation at Shanhe in Zhenfeng County, an assemblage of approximately Anisian age consists of agglutinated species ('Ammobaculites' wirzi, Tolypammina sp., Textularia spp., Ammodiscus sp. and Verneuilinoides parva.) Of these, only 'Ammobaculites' (Endothyranella) wirzi is present in Hampton-1.

Scythian or Anisian Foraminifera described from Burma by Zaninetti \& Whittaker (1980) are from dolomites. The faunas, 


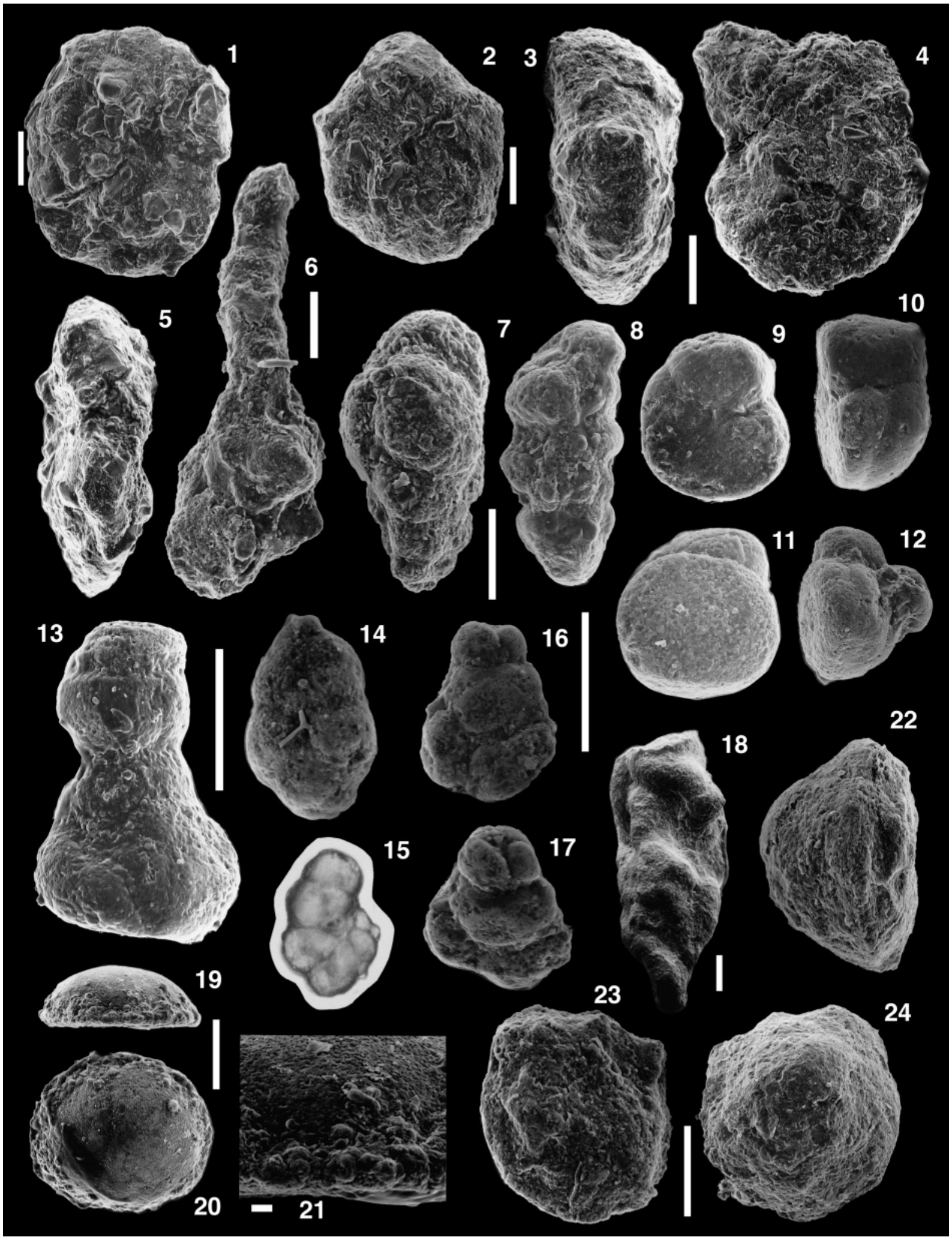


all species of Glomospira, are Tethyan in type, and entirely different from the Hampton-1 assemblages.

Oberhauser (1960) illustrated ten species, as part of a Ladinian assemblage from NE Iran which has some similarity with the Hampton-1 assemblages. Species in common include Dentalina ex. gr. subsiliqua (=Prodentalina terquemi of this paper), Lingulina aghdarbandi (=Lingulina alaskensis), Lingulina tenera, and Lingulina iranica $(?=$ Lingulina borealis $)$. In the same paper, assemblages from the Ladinian of the Alps are illustrated. Similarities to the Hampton-1 assemblages are much less from this area; species in common include Lingulina klebelsbergi (=Lingulina borealis), Dentalina vadaszi (=Nodosaria vadaszi), and Globigerina ladinica (=Oberhauserella ladinica).

In the 'Sephardic' realm of the Triassic Tethys in Israel, Benjamini (1984) reports on two Anisian foraminiferal assemblages in a predominantly carbonate environment. Dominant genera are Tolypammina and Glomospira, with some nodosarids and Lingulina sp. Glomospira is present in low numbers in Hampton-1, and encrusting foraminifera are low in numbers. Details of other species present in the Israeli assemblages are insufficient for comparison.

In Poland, Styk (1975) described assemblages from the upper part of the Lower Triassic of Poland. The assemblages, of some 36 species, as in Hampton-1 consist of a wide range of genera including dominantly Nodosariidae, but with Lingulina and miliolids. Species in common with Hampton-1 include Pachyphloides klebelsbergi (=Lingulina borealis) and Kollmannita cf. ladinica (=Oberhauserella ladinica).

\section{SYSTEMATIC DESCRIPTIONS}

The foraminifera are listed in the orders used in Loeblich \& Tappan (1987), although reservations are expressed in the text as to the definition of some genera. If these doubts prove to be correct, a rearrangement of some genera within larger taxonomic groups (including suborders) may be necessary. Some taxonomic problems encountered here will require detailed thin section and SEM study of wall ultrastructure to resolve them. This has not been possible in the scope of the present study.

All illustrated and type specimens (except for one specimen) are deposited in the collections of the Western Australian Museum, Francis St, Perth, Western Australia, under the catalogue numbers WAM 02.320-WAM 02.402. The museum catalogue numbers are given in the plate captions, followed by the author's original numbering in parentheses. Some specimens photographed in transmitted light were lost after photography and, therefore, do not have museum numbers.

\section{Suborder Textulariina Delage \& Hérouard, 1896 \\ Family Ammodiscidae Reuss, 1862 \\ Genus Ammovertella Cushman, 1928}

Ammovertella sp. cf. inclusa (Cushman \& Waters)

1927 Psammophis inclusus Cushman \& Waters: 148, pl. 26, fig. 12.

1958 Ammovertella $\mathrm{cf}$. inclusa (Cushman \& Waters); Crespin: 72, pl. 18, fig. 5.

Remarks. Specimens of a finely agglutinated tubular form with a grey, siliceous-appearing cement are tentatively identified, following Crespin. The tubes, which are about 100 to $150 \mu \mathrm{m}$ in diameter, are wound irregularly around themselves, or around a shell or other surface of attachment, and change direction abruptly. In places the tubes are slightly constricted. Length of specimens up to $0.7 \mathrm{~mm}$.

Genus Glomospira Rzehak, 1885

Glomospira sp. cf. G. adhaerens Parr, 1942

1942 Glomospira adhaerens Parr: 103, pl. 1, fig. 2 (fide Crespin).

1958 Glomospira adhaerens Parr; Crespin: 70, pl. 13, figs 6, 7. 1967 Glomospira adhaerens Parr; Ludbrook: 79, pl. 4, figs 1-4.

Remarks. The species was described from the Lower Permian of Western Australia and South Australia. It is found as a single specimen in Hampton-1 at 2125-2130 m.

Family Haplophragmoididae Maync, 1952

Genus Haplophragmoides Cushman, 1910

\section{Haplophragmoides sp. A}

(P1. 1, figs 1, 5)

1986 Haplophragmoides wilgunyaensis Crespin, 1963: Heath \& Apthorpe: 317, pl. 1, figs 1-2.

Remarks. The species present in Hampton-1 was believed to be the Cretaceous Haplophragmoides wilgunyaensis Crespin. However, D. Haig (pers. comm., 2000) states that the holotype of $H$. wilgunyaensis is crushed, and partly evolute on one side. All the paratypes are partly evolute on one side. The present species is involute, with a shallow central umbilical depression, and

\section{Explanation of Plate 1.}

figs 1, 5. Haplophragmoides sp. A, WAM 02.320 (M87-6), Hampton-1, 2460-2465 m: 1, side view, $\times 94 ;$ 5, apertural view, $\times 112$; scale bar 100 $\mu$ m. figs 2, 3. Haplophragmoides sp. B, WAM 02.321 (M87-5), Hampton-1, 2460-2465 m: 2, side view, $\times 94$; 3, edge view, $\times 112$; scale bar 100 $\mu$ m. fig. 4. Kutsevella? sp., WAM 02.322 (M87-10), Hampton-1, 2170-2175 m, side view, $\times 112$; scale bar 100 um. fig. 6. ??Ammobaculites sp., WAM 02.323 (M80-5), Hampton-1, 2285-2290 m, side view, × 112. fig. 7. Verneuilinoides mauritii (Terquem), WAM 02.324 (M80-3), Hampton-1, 2285-2290 m, side view, $\times 150$; scale bar $100 \mu \mathrm{m}$. fig. 8. Gaudryina sp., WAM 02.325 (M34-25), Hampton-1, $2169 \mathrm{~m}$, slightly oblique side view; $\times 150$; scale bar $100 \mu \mathrm{m}$. figs 9, 10. Endothyra cf. küpperi Oberhauser: 9, spiral view; 10, edge view; both WAM 02.326 (W79-22), Hampton-1, 2169 m; $\times 225$; scale bar $100 \mu \mathrm{m}$ for figs 9-17. figs 11-12. incertae sedis: 11, spiral view or terminal chamber(?), possibly of an endothyrid; 12, edge view; both WAM 02.327 (W79-24), Hampton-1, 2240-2245 m, × 225. figs 13-17. Endothyranella wirzi (Koehn-Zaninetti): 13, WAM 02.328 (M1-3), side view, $\times 225$; 14, WAM 02.329 (M1-5), side view, $\times 225$; 15, specimen lost, viewed in transmitted light; 16, 17, WAM 02.330 (M1-6) - 16, side view, $\times 225$, 17 oblique apertural/side view, $\times 225$, all from Hampton-1, $2169 \mathrm{~m}$. fig. 18. Calcitornella elongata Cushman \& Waters, WAM 02.338 (W78-29), Hampton-1, 2169 m, side view, ×75; scale bar $100 \mu \mathrm{m}$. figs 19-21. Calcitornella heathi Cushman \& Waters, WAM 02.339 (M87-9), Hampton-1, 2170-2175 m: 19, edge view; 20, view of unattached side, $\times 112$; scale bar for figs 19-20 $100 \mu \mathrm{m}$; 21, detail of nodular margin and surface of unattached side; scale bar for fig. 21, $10 \mu \mathrm{m}$. figs 22-24. Trocholina sp., WAM 02.331 (M80-1), Hampton-1, 2285-2290 m: 22, edge view; 23, umbilical view; 24, spiral view; all $\times 150$. 
essentially symmetrical appearance on both sides. The margin is compressed. Many specimens are somewhat deformed. The same species also occurs in the Triassic of the Lawley-1 well (Heath \& Apthorpe, 1986).

Palaeoecology. Haplophragmoides is virtually absent above $2340 \mathrm{~m}$, but between that depth and $2465 \mathrm{~m}$ it is the dominant genus in the sparse foraminiferal assemblages. It reaches a peak of abundance between $2400 \mathrm{~m}$ and $2430 \mathrm{~m}$. This dominance is believed to indicate a down-sequence change in the depositional environment, to paralic or delta-influenced conditions.

\section{Haplophragmoides sp. B}

(Pl. 1, figs 2-3)

Remarks. A species of Haplophragmoides with a broader, more rounded periphery than $H$. sp. A, shallow sutures, and with more involute coiling, resulting in a very small or obscured umbilical depression. It occurs in association with H. sp. A.

\section{Genus Kutsevella Dain, 1978}

Kutsevella? sp.

$$
\text { (P1. 1, fig. 4) }
$$

Remarks. A compressed, Haplophragmoides-like planispirally coiled specimen found at 2170-2175 m has a tapering, separated final chamber. It is similar to specimens of Kutsevella figured from the Jurassic by Nagy \& Basov (1998). The aperture on the present specimen cannot be seen clearly, but it may be terminal or areal.

Genus Trochammina Parker \& Jones, 1859

Trochammina sp. cf. T. subobtusa Parr, 1942

1958 cf. Trochammina subobtusa Parr, 1942; Crespin: 92, pl. 21, figs $5-6$.

Remarks. Deformed specimens tentatively attributed to this Permian species occur sporadically in small numbers between $2125 \mathrm{~m}$ and $2360 \mathrm{~m}$ in Hampton-1.

\section{Genus Gaudryina d'Orbigny, 1839 \\ Gaudryina sp. \\ (Pl. 1, fig. 8)}

Remarks. A single specimen $270 \mu \mathrm{m}$ in length was found at $2169 \mathrm{~m}$, and a second specimen at $2285-2290 \mathrm{~m}$. The figured specimen has a fairly quadrate profile when viewed from the apertural end.

Genus Verneuilinoides Loeblich \& Tappan, 1949

Verneuilinoides mauritii (Terquem, 1866)

$$
\text { (P1. 1, fig. 7) }
$$

1866 Verneuilina mauritii Terquem: 448, pl. 18, fig. 18a-b (fide Ellis \& Messina, 1940 et seq.).
1988 Verneuilinoides mauritii (Terquem); Kristan-Tollmann: 248, fig. 1 (18-22).

Remarks. Two triserial specimens, $0.3-0.4 \mathrm{~mm}$ long, appear to correspond to this species. The wall is rough, and composed of abundant silt grains set in a small amount of matrix of unknown composition. The figured specimen is the best preserved. The aperture has not been clearly seen. It may consist of a small arched opening on the basal suture of the last chamber.

The species was originally described from the Early Jurassic of France. Kristan-Tollmann (1988) figured drawings of specimens from the Late Triassic of Austria, the Carnian of Turkey and Timor, and the Rhaetian of Papua-New Guinea.

\section{Suborder Fusulinina Wedekind, 1937 \\ Family Endothyridae Brady, 1884 \\ Genus Endothyra Phillips, 1846}

Endothyra cf. küpperi Oberhauser, 1960

(Pl. 1, figs 9-10)

1960 Endothyra küpperi Oberhauser: 16, tafel 3, figs 7a-c, 14a-c, 22.

Remarks. A single specimen of this enrolled, involute form was found at $2169 \mathrm{~m}$, and a second, somewhat dubious specimen at $2240-2245 \mathrm{~m}$. The figured specimen is flatter on one side than on the other, and has a slightly more truncate margin than Oberhauser's species. The maximum diameter is about $120 \mu \mathrm{m}$

Incertae sedis

(P1. 1, figs 11-12)

Remarks. A planoconvex specimen of a possible endothyrid was found at 2240-2245 m. No internal chamber arrangement could be seen. In the SEM the specimen appears to be composed of several coiled chambers. In the sample at $2169 \mathrm{~m}$, very small specimens, composed of one to three chambers, may be of a similar form. These are possibly juveniles of an as yet unrecognized species.

\section{Genus Endothyranella Galloway \& Harlton, 1930}

Endothyranella wirzi (Koehn-Zaninetti, 1968)

(P1. 1, figs 13-17)

1968 Ammobaculites wirzi Koehn-Zaninetti: nomen nudum. 1969 Ammobaculites wirzi Koehn-Zaninetti: fig. 5, A-D, F-K. 1976 Endothyranella wirzi (Koehn-Zaninetti); Zaninetti: 129, pl. 4, figs 2-4, pl. 8, figs 26-30.

See Zaninetti (1976) for synonymy.

Remarks. Very rare small specimens referable to this species are present between $2125-2130 \mathrm{~m}$ and the core at $2169 \mathrm{~m}$ in Hampton-1. Specimens show an initial coil with four chambers visible on the exterior, plus one to three uncoiled chambers. The plane of the early coil appears to be at an angle to that of the uncoiled part of the test (see Pl. 1, figs 13, 15). The aperture is terminal. In one photographed specimen (Pl. 1, fig. 14) the aperture is produced on a short neck, whereas in another (Pl. 1, 
fig. 17), the aperture lacks a neck and is a larger opening with possible radiating slits. Further study of the species from additional specimens is required.

\section{Suborder Involutinina Hohenegger \& Piller, 1977 \\ Family Involutinidae Bütschli, 1880 \\ Genus Arenovidalina He, 1959}

\section{Arenovidalina? sp.}

1983 ? 'Arenovidalina chialingchiangensis' Ho; KristanTollmann: 296, Abb. 1, figs 10-12.

Remarks. Very rare small specimens are tentatively referred to this genus. Piller (1983) has indicated that Arenovidalina does not belong within the Involutinina. The specimens are externally similar to Anisian specimens figured by Kristan-Tollmann (1983) from China, but pending thin section study, no decision is possible as to the correct generic placement.

Genus Trocholina Paalzow, 1922

Trocholina planoconvexa sp. nov. (Pl. 2, figs 1-7)

Derivation of name. Describing the shape.

Diagnosis. Small planoconvex Trocholina with a low spire and a step-like profile on the spiral side.

Holotype. WAM 02.332 (W69-14), Hampton-1 well, 2240 $2245 \mathrm{~m}$ (ditch cutting sample): Pl. 2, figs 1-3.

Type level. Undifferentiated late Spathian to Anisian in age.

Figured paratype. WAM 02.333 (M80-4), Hampton-1 well, 2285-2290 m: Pl. 2, figs 4-7.

Unfigured paratypes. 'A' (WAM 02.334) and 'B' (WAM 02.335) both from Hampton-1 well, 2180-2185 m; 'C' (WAM 02.336) from Hampton-1 well, 2170-2175 m.

Description. Test small (diameter $0.1-0.25 \mathrm{~mm}$ ); calcareous; planoconvex. The low convex side consists of a spiral of six to seven whorls, defined by the step-like profile of this side of the test, which is clearly seen in the holotype and paratypes. Umbilical side of test flat, with an irregular, poorly defined umbilical depression. The entire umbilical side appears to be covered with irregular nodules, which are difficult to see due to the very small size of the specimens. The holotype is the best preserved of the eleven specimens found. The wall surface as seen in the SEM is finely and irregularly pitted (see Pl. 2, figs 5-7), but this may be a diagenetic effect. Broken areas of wall appear to be of heavily recrystallized calcite crystals aligned perpendicular to the surface (Pl. 2, fig. 4).

Comparison with other species. This small, low-spired Trocholina differs from $T$. permodiscoides Oberhauser (1964) and T. biconvexa Oberhauser (1957) by being planoconvex rather than slightly biconvex, and also by the 'step-like' definition of the whorls on the spiral side. From $T$. ventroplana Oberhauser, the new species differs in having a lower spire, and a nodular umbilical surface. From T. plagiostoma Tollmann \& Kristan-Tollmann (as reproduced by Zaninetti, 1976), T. planoconvexa $\mathrm{n}$. sp. differs in having a slower rate of chamber expansion in the final whorl and in lacking the prominent growth lines figured on T. plagiostoma. Nodules cover the entire umbilical side of the holotype of T. planoconvexa, rather than being confined to the umbilical area only. However, in the figured paratype (Pl. 2, fig. 7) the nodular covering does not extend to the final part of the chamber.

Dimensions. Holotype WAM 02.332 (W69-14; from 2240$2245 \mathrm{~m}$; Pl. 2, figs 1-3): diameter $0.24 \mathrm{~mm}$; height $0.11 \mathrm{~mm}$. Figured paratype WAM 02.333 (M80-4; from 2285-2290 m; Pl. 2, figs 4-7), maximum diameter $0.29 \mathrm{~mm}$; height $0.125 \mathrm{~mm}$. Unfigured paratype 'A', WAM 02.334 from 2180-2185 m, diameter $0.25 \mathrm{~mm}$; paratype 'B', WAM 02.335 from $2180-2185 \mathrm{~m}$, diameter $0.18 \mathrm{~mm}$; paratype 'C', WAM 02.336, from 2170 $2175 \mathrm{~m}$, diameter $0.13 \mathrm{~mm}$, height c. $0.06 \mathrm{~mm}$. ?Juvenile (from sidewall core at $2169 \mathrm{~m}$ ), diameter $0.1 \mathrm{~mm}$; three specimens from ditch cutting sample at $2240-2245 \mathrm{~m}$, diameters all $0.22 \mathrm{~mm}$.

Occurrence. Hampton-1 well, 2125-2130 m (ditch cutting) to $2169 \mathrm{~m}$ (sidewall core) to 2285-2290 m (ditch cutting sample); 11 specimens found; most very poorly preserved.

Trocholina sp.

(Pl. 1, figs 22-24)

Dimensions. Diameter approximately $0.24 \mathrm{~mm}$; height of spiral side $0.11 \mathrm{~mm}$; height of umbilical side, approximately $0.06 \mathrm{~mm}$.

Remarks. One specimen of a small Trocholina was found at 2285-2290 m (figured) and a second, similar specimen at 2190 $2195 \mathrm{~m}$. The preservation of both is poor, with the edges of the figured specimen being broken. The spiral side is moderately high, and the surface essentially smooth, unlike $T$. planoconvexa, above. The umbilical side is slightly convex. No other features are discernible in the SEM.

\section{Suborder Miliolina Delage \& Hérouard, 1896 \\ Family Hemigordiopsidae A. Nikitina, 1969 \\ Genus Hemigordius Schubert, 1908}

Hemigordius schlumbergi (Howchin, 1895)

1895 Cornuspira schlumbergi Howchin, M.S. 1893: 195, pl. 10, figs 1-3 (fide Crespin, 1958).

1958 Hemigordius schlumbergi (Howchin); Crespin: 81, pl. 16, figs 7-9, pl. 31, figs 4-5.

Remarks. Small, non-descript and badly preserved specimens appear to be referable to this Permian species. Sparse in number; scattered through the section between $2150 \mathrm{~m}$ and $2445 \mathrm{~m}$.

\section{Hemigordius volutus Palmieri, 1985}

(P1. 2, figs 18-19)

1985 Hemigordius volutus Palmieri, in Foster et al.: 82, pl. 6, figs 10-14.

Remarks. Ovoid compressed specimens of Hemigordius, with an evolute coil, irregular plane of coiling, and non-embracing 


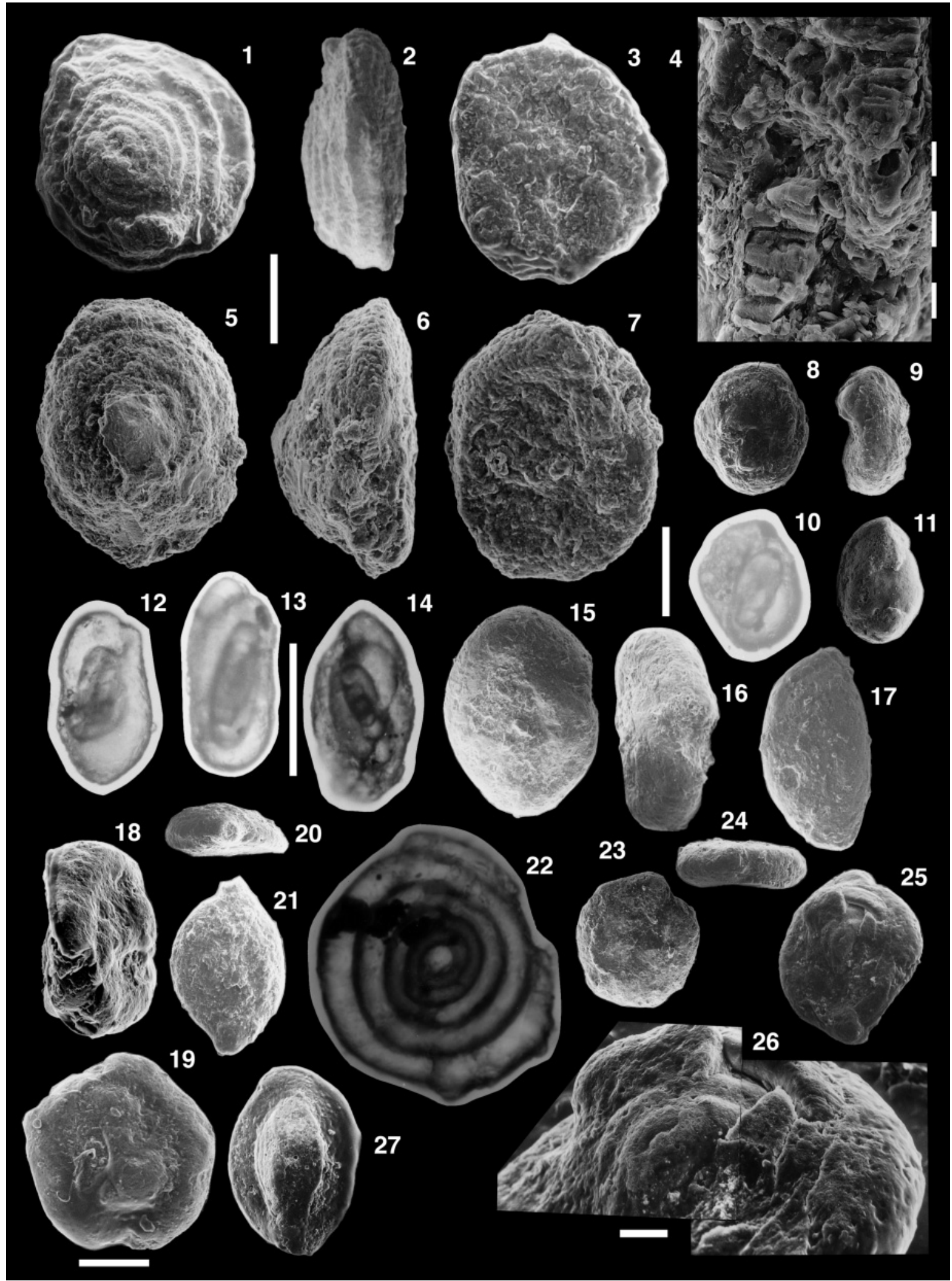


chambers appear to belong within $H$. volutus, rather than within the more regularly coiled, more involute $H$. schlumbergi. Both forms appear to be present in Hampton-1, but poor preservation of many specimens prevents definite assignment to one or other species in some cases.

Family Cornuspirinae Schultze, 1854 Genus Calcitornella Cushman \& Waters, 1928

Calcitornella elongata Cushman \& Waters, 1928

(Pl. 1, fig. 18)

1958 Calcitornella elongata Cushman \& Waters; Crespin: 82, pl. 17, figs 1-3.

Remarks. Specimens with an irregularly coiled tubular calcareous test with a roughened exterior, coiled around a spine or other object, occur rarely from $2169 \mathrm{~m}$ to $2295 \mathrm{~m}$ in Hampton-1.

\section{Calcitornella heathi Cushman \& Waters, 1928}

$$
\text { (Pl. 1, figs 19-21) }
$$

1958 Calcitornella heathi Cushman \& Waters; Crespin: 83, pl. 13, figs 8-11, pl. 19, fig. 11.

1985 Calcitornella heathi Cushman \& Waters; Palmieri in Foster et al: : 80-81, pl. 5, fig. 14, pl. 6, figs 15-16.

Remarks. This is a medium-size, scale-like attached form, with a low domed free surface, a nodular thickened margin and an irregular coiled tubular chamber revealed on the broken attached surface. Occurs rarely from $2169 \mathrm{~m}$ to $2295 \mathrm{~m}$ in Hampton-1.

Family Ophthalmidiidae Wiesner, 1920

Genus Gsollbergella Zaninetti, 1979

Gsollbergella spiroloculiformis Oraveczné Scheffer, 1968

(Pl. 2, figs 8-16, ?17)

1968 Agathammina spiroloculiformis Oraveczné Scheffer: 91, pl. 2, figs $1-5$.

1969 Agathamminoides gsollbergensis Zaninetti: 699, fig. 1.

1976 Agathamminoides spiroloculiformis (Oraveczné Scheffer); Zaninetti: 147, pl. 5, figs 10-14, pl. 7, figs 1-2.

1979 Gsollbergella spiroloculiformis (Oraveczné Scheffer); Zaninetti: 73 .
Remarks. Rare to moderately common in many samples down to $2360 \mathrm{~m}$ in Hampton-1. Variable, ovate outline, compressed, with broadly rounded margin. Chambers externally poorly defined due to preservation. Some specimens in transmitted light reveal a chamber arrangement identical to that figured by Zaninetti (1976, pl. 5, figs 10-14), with a globular proloculus, followed by chambers in a quinqueloculine arrangement, but with the separation between chambers poorly defined.

Zaninetti (1969) described this species as Agathamminoides gsollbergensis, the type species for her new genus Agathamminoides. However, the name Agathamminoides was preoccupied by the agglutinated genus Agathamminoides Vangerow, 1964. In 1979 Zaninetti, therefore, renamed her genus Gsollbergella, with the type species gsollbergensis recognized as a synonym of Agathammina spiroloculiformis Oraveczné Scheffer, 1968.

\section{Genus Karaburunia Langer, 1968}

?Karaburunia rendeli Langer

(Pl. 2, figs 20-21)

1968 Karaburunia rendeli Langer: 591-592, pl. 1, figs 6-8.

Remarks. Only one specimen is doubtfully referred to this species. It is more compressed than Langer's illustrated specimens, but has a similar aperture on a neck, which is partly broken off. K. rendeli was described from the Anisian of Turkey.

Genus Ophthalmidium Kübler \& Zwingli, 1870

Ophthalmidium sp. A

(P1. 2, figs 22-24)

Description. A small species with a round to slightly oval outline, flat parallel sides, sometimes slightly depressed central area and broadly rounded margin. Most specimens are poorly preserved and their chamber structure is obscure. One specimen (Pl. 2, fig. 22) in transmitted light shows a spherical initial chamber, followed by a tubular second chamber one whorl in length, followed by three chambers each half a whorl in length; later chambers are roughly half a whorl in length, but with only slight constriction or partitioning at the end of later chambers. The earlier chambers are widest at their initial end and taper slightly

Explanation of Plate 2

figs 1-3. Trocholina planoconvexa $\mathrm{n}$. sp., holotype, WAM 02.332 (W69-14), Hampton-1, 2240-2245 m: 1, spiral; 2, edge; 3, umbilical views; all $\times 150$. figs 4-7. Trocholina planoconvexa $\mathrm{n}$. sp., paratype, WAM 02.333 (M80-4), Hampton-1, 2285-2290 m: 4, detail of broken wall and possible chamber infilling in two chambers (shown from different angle in fig. 6), white scale bars on edge $10 \mu \mathrm{m} ; \mathbf{5}$, spiral; 6, edge; 7, umbilical views; all $\times 150$; scale bar $100 \mu \mathrm{m}$, applies to figs 1-3, 5-7. figs 8-16. Gsollbergella spiroloculiniformis (Oraveczné Scheffer): 8, 9, WAM 02.340 (W001-87), Hampton-1, $2169 \mathrm{~m}$, side and edge views, $c . \times 150$; scale bar to left of fig. 10 is $100 \mu \mathrm{m}-$ applies to figs $8-11,15-17,20-21,23,24,27) ; 10$, transmitted light view; 11. WAM 02.341 (W75-14), Hampton-1, 2290-2295 m, side view, $\times 150$; 12, WAM 02.342 (W349-57), Hampton-1, 2169 m, transmitted light, c. $\times 225$; 13, W349-61, specimen lost, Hampton-1, $2169 \mathrm{~m}$, transmitted light, c. $\times 225 ; 14$, W349-60, specimen lost, Hampton-1, SWC 2169 m, c. $\times 150$; scale bar between figs 13 and 14 is $100 \mu \mathrm{m}$ and applies to figs 12-14; 15, 16, WAM 02.343 (W75-15), Hampton-1, 2290-2295 m - 15, side view; 16, oblique apertural view, $\times 150 ; 17$, ? Gsollbergella spiroloculiniformis (Oraveczné Scheffer), side view, WAM 02.344 (W75-1), Hampton-1, 2290-2295 m, × 150. figs 18, 19. Hemigordius volutus Palmieri, WAM 02.337 (M87-11), Hampton-1, 2170-2175 m: 18, oblique edge view, showing apertural region at centre of edge; 19, side view; both $\times 112$; scale bar $100 \mu \mathrm{m}$ for figs 18, 19. figs 20, 21. ?Karaburunia rendeli Langer, WAM 02.345 (W75-11), Hampton-1, 2290-2295 m: 20, apertural view; 21, side view; both $\times 150$. figs 22-24. Ophthalmidium sp. A: 22, WAM 02.346 (W349-47), Hampton-1, 2125-2130 m, transmitted light view to show chamber arrangement, $\times 300 ; 23$, 24, WAM 02.347 (W75-12), Hampton-1, 2290-2295 m - 23, side view, 24, edge view, both $\times 150$. figs 25, 26. Ophthalmidium sp. B, WAM 02.348 (W76-11), Hampton-1, 2200-2205 m: 25, oblique side view, $\times 225$; 26, enlargement of oblique view of fig. $25, \times 750$, to show apparently pitted wall texture; scale bar for fig. 26 c. $10 \mu \mathrm{m}$. fig. 27. Quinqueloculina sp. cf. Q. nucleiformis Kristan-Tollmann, WAM 02.349 (W78-26), Hampton-1, 2180-2185 m, side view, $\times 150$. 


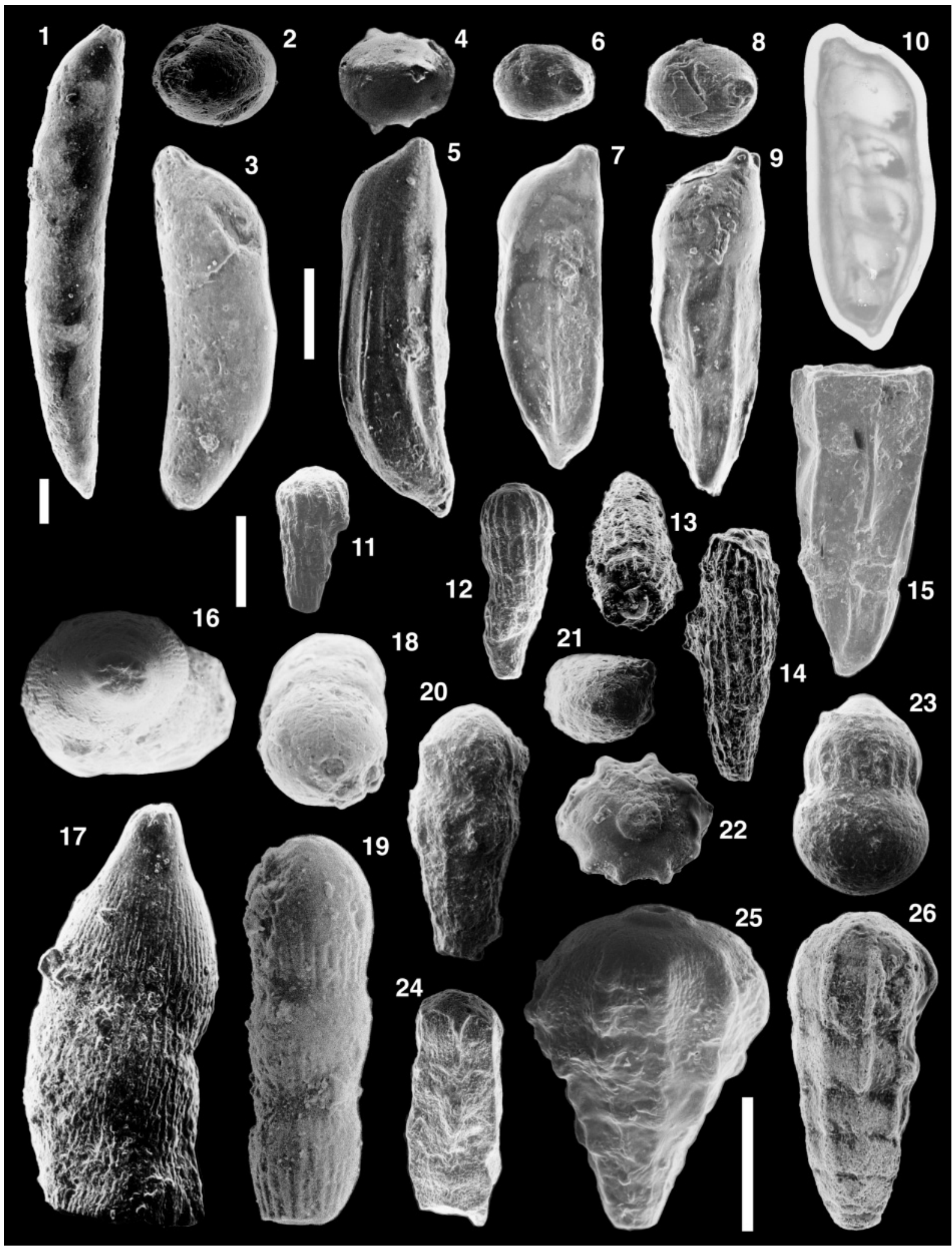


towards the apertural end, forming a 'milioline-looking' early stage. The later chambers taper less, and form a more circular outline. The aperture is a simple opening at the end of the last chamber (Pl. 2, fig. 24). Wall calcareous, but the microstructure is unknown.

Remarks. The parallel sides and absence of secondary thickening, plus the slightly tapering but poorly divided chambers, suggest that this species is best referred to Ophthalmidium rather than Eoophthalmidium Langer or Praeophthalmidium Burbach.

\section{Ophthalmidium sp. B}

(Pl. 2, figs 25-26)

1981 ? Ophthalmidium sp. Goel et al.: pl. 1, fig. 8. 1986 Ophthalmidium orbiculare Burbach; Heath \& Apthorpe: 317, pl. 1, figs 4-8.

non 1983 Ophthalmidium triadicum (Kristan); Kristan-Tollmann: abb. 2, figs 17-22, tafel 4, figs 1-2.

Remarks. An elongate Ophthalmidium, with a chamber coiling which appears to be more evolute than Eoophthalmidium Langer. The chamber surface appears to be pitted in Hampton-1 (Pl. 2, fig. 26), although this may be due to poor preservation. The specimens have a broader, less leaf-shaped outline than Ophthalmidium triadicum (Kristan) from the Anisian of South China (Kristan-Tollmann, 1983). They are not conspecific with Ophthalmidium orbiculare Burbach (J. Hohenegger, 1995, pers. comm.). Both forms of Ophthalmidium found in Hampton-1 require further study and thin sectioning.

\section{Genus Quinqueloculina d'Orbigny, 1826}

Quinqueloculina sp. cf. Q. nucleiformis Kristan-Tollmann, 1964

$$
\text { (Pl. 2, fig. 27) }
$$

1964 cf. Quinqueloculina nucleiformis Kristan-Tollmann: 61, pl. 9, figs 9-11.

Remarks. Two specimens, from 2180-2185 m and 2220-2225 m, are similar to the Rhaetian species Quinqueloculina nucleiformis Kristan-Tollmann, 1964, but have chambers that are slightly less produced at the aperture.
Suborder Lagenina Delage \& Hérouard, 1896

Family Ichthyolariidae Loeblich \& Tappan, 1986 Genus Paralingulina Gerke, 1969

Paralingulina tenera (Bornemann, 1854)

(Pl. 4, figs 12-13)

1854 Lingulina tenera Bornemann: 38: fide Ellis \& Messina, 1940 et seq.

1960 Frondicularia tenera tenera Bornemann; Oberhauser: 37, pl. 1, figs 47-51, pl. 6, fig. 9 .

1964 Lingulina tenera concosta Kristan-Tollmann: 141, pl. 30, figs $8-12$.

1979a Lingulina tenera Bornemann; Haig: 212, fig. 2, 1-2.

1981 Geinitzinita tenera (Bornemann); Quilty: 10, pl. 2, figs 1-6, text-fig. 4.

1983 Lingulina tenera carinata (Nørvang); Kristan-Tollmann: 292, pl. 3, figs 9, 13.

1983 Lingulina tenera substriata (Nørvang); Kristan-Tollmann: 292, pl. 3, fig. 12.

1984 Lingulina tenera tenera Bornemann; Strong: 29-30, pl. 5, figs 114-119, pl. 12, figs 243-248.

1986 Lingulina tenera Bornemann; Heath \& Apthorpe: 332, pl. 8, figs 23-30.

1987 Paralingulina tenera (Bornemann); Loeblich \& Tappan: 391, pl. 433, figs 3-4.

Remarks. This group occurs as rare specimens in most samples between $2125 \mathrm{~m}$ and $2345 \mathrm{~m}$. The specimens display the same variation in ornament as seen in Lawley-1 well: ranging from specimens with two heavy longitudinal ribs outlining each lateral face, to specimens with the lateral ribs very faintly developed. Preservation is very poor. The partial synonymy above emphasizes Triassic (Anisian) occurrences of Paralingulina tenera, which ranges at least from the Spathian (this paper) to the Pliensbachian, plus two Jurassic published records for the species in Papua-New Guinea and New Zealand. The geographical distribution of the species in the Anisian to Rhaetian ranges from the Alps, through Iran, to Australia and South China. The numerous records of the species for the Early Jurassic are not given here.

Explanation of Plate 3.

figs 1-3. Prodentalina terquemi (d'Orbigny): 1, WAM 02.350 (M88-6), Hampton-1, 2220-2225 m, side view, $\times 75$; scale bar 100 $\mu$ m; 2, apertural; and 3, side views of WAM 02.351 (M88-2), Hampton-1, $2169 \mathrm{~m}, \times 150$. Scale bar $100 \mu \mathrm{m}$ for figs 2-24, 26. figs 4-10, 15. Dentalina septacosta n. sp.: 4, apertural; and 5, side views of holotype, W49-3 (Geological Survey of Western Australia collection F46840), Lawley-1, SWC 635.1 m, c. × 150; 6, apertural; and 7, side views of paratype WAM 02.352 (M1-7), Hampton-1, SWC $2169 \mathrm{~m}, \times 150$; 8, apertural; and 9, side views of WAM 02.353 (M88-3), Hampton-1, SWC 2169 m, × 150; 10, side view of WAM 02.354 (W001-88), Hampton-1, SWC 2169 m, in transmitted light, to show linear chamber arrangement and shadow of two of the longitudinal external costae; 15, side view, rotated slightly towards the ventral border, of the largest but broken specimen WAM 02.355 (M1-4), Hampton-1, SWC $2169 \mathrm{~m}, \times 150$. figs 11-14. Nodosaria sp. cf. N. irwinensis Howchin: 11, side view of WAM 02.356 (W79-1); 12, side view of WAM 02.357 (W78-25), both from Hampton-1, SWC 2169 m; 13, oblique apertural; and 14, side views of broken specimen WAM 02.358 (M89-1), Hampton-1, 2210-2215 m, all $\times 150$. Note the broad apertural lip around the circular aperture in figs 12 and 13. figs 16, 17. Dentalina sp.: 16, apertural; and 17, side views of broken specimen WAM 02.359 (W69-16), Hampton-1, 2200-2205 m $\times 150$; scale bar $100 \mu \mathrm{m}$. figs 18, 19. Nodosaria sp. A: 18, oblique apertural; and 19, side views, WAM 02.360 (M38-2), Hampton-1, 2270-2275 m, $\times 150$. figs 20, 21. Nodosaria sp. cf. springsurensis Crespin: 20, side; and 21, apertural views of WAM 02.361 (W69-15), Hampton-1, 2200-2205 m, $\times 150$. fig. 23. Nodosaria vadaszi (Oberhauser), side view of WAM 02.362 (W78-27), Hampton-1, $2169 \mathrm{~m}, \times 150$. figs 22, 24-26. Nodosaria plochingeri (Oberhauser): 22, apertural view, $\times 150 ; 25$, side view, $\times 225$; both of WAM 02.363 (W69-11), Hampton-1, 2240-2245 m; note the minute striae between the costae on the last chamber; 24, side view of parallel-sided form, WAM 02.364 (W78-20), Hampton-1, 2169 m, $\times 150 ; \mathbf{2 6}$, side view of weakly tapering form, WAM 02.365 (M87-1), Hampton-1, 2460-2465 m, × 150; scale bar $100 \mu \mathrm{m}$ for fig 25 only. 


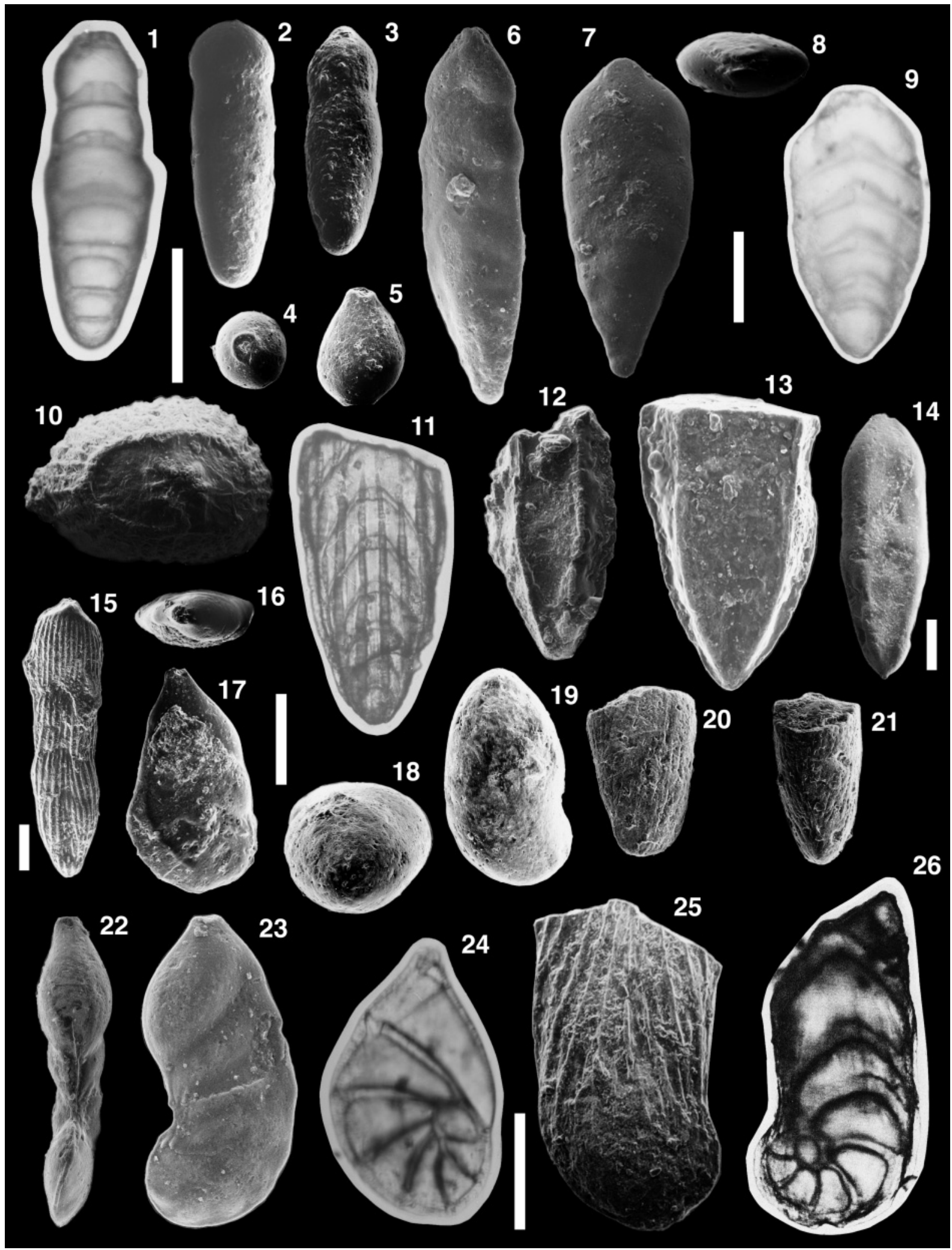


Triassic Foraminifera from Western Australia

Genus Prodentalina Norling, 1968

Prodentalina terquemi (d'Orbigny, 1850)

(Pl. 3, figs 1-3)

1850 Dentalina terquemi d'Orbigny; Ellis \& Messina: 1940 et seq.

1955 Dentalina terquemi d'Orbigny; Tappan: 66, pl. 23, figs $1-4$.

1964 Dentalina terquemi d'Orbigny; Kristan-Tollmann: 96, pl. 15, figs 12-15, pl. 17, fig. 18.

1968 Prodentalina terquemi (d'Orbigny); Norling: 34, [fide Loeblich \& Tappan, 1987].

1976 Dentalina terquemi d'Orbigny; Nicora \& Premoli-Silva: 492, pl. 1, fig. 5.

1986 Dentalina terquemi d'Orbigny; Heath \& Apthorpe: 319, pl. 1, figs 21-23.

1987 Prodentalina terquemi (d'Orbigny); Loeblich \& Tappan: 391, pl. 434, figs 12-16.

Remarks. The species is abundant in the sample at $2169 \mathrm{~m}$, and sparse but present in nearly all samples between $2125 \mathrm{~m}$ and $2345 \mathrm{~m}$. Most specimens are broken. It is also moderately common in Lawley-1 well (Heath \& Apthorpe, 1986). Apart from the numerous records in the Jurassic, Triassic records include Kristan-Tollmann (1964), from the Norian-Rhaetian of Austria, and Nicora \& Premoli-Silva (1976), from the Anisian of Greece.

Prodentalina septacosta $\mathrm{sp}$. nov.

(Pl. 3, figs 4-10, 15)

1986 Dentalina sp. Heath \& Apthorpe: 319, pl. 1, figs 19-20.

Derivation of name. From the number of costae (usually seven) ornamenting the test.

Holotype. Plate 3 (figs 4-5) of the Geological Survey of Western Australia collection no. F46840 (W49-3): Lawley-1 well, sidewall core at $635.1 \mathrm{~m}$

Paratypes. Plate 3 (figs 6-7, 10) of the Western Australian Museum collection no. WAM 02.352 (M1-7) and Plate 3 (figs 8-9) (WAM 02.353 (M88-3)), both from Hampton-1 well, sidewall core at $2169 \mathrm{~m}$.
Material. Six specimens: Lawley-1 well, sidewall core at $635.1 \mathrm{~m}$, one specimen (holotype); Hampton-1 well, sidewall core at $2169 \mathrm{~m}$, four specimens; and ditch cutting at 2130-2135 m, one specimen: all Spathian-Anisian in age.

Description. Test moderately large, robust, elongate, chamber arrangement uniserial, rectilinear as for Dentalina, slightly laterally compressed. In most specimens, large initial chamber with a blunt basal spine, followed by 4-(5?) chambers, wider than high. Sutures generally flush and chambers not inflated, except for the final chamber, which has a slightly depressed suture and is gently inflated. Aperture strongly eccentric, produced. Remnants of a radiate structure can be seen around the apertural opening, which is damaged in all specimens. Ornament consisting of seven or sometimes eight prominent thick raised costae, all but two extending from near the initial spine. The costae are almost parallel to the length of the test. They extend continuously over the first four chambers, and disappear near the base of the final chamber, which is smooth. They are evenly spaced around the test, so that usually four costae are visible from either side. On the paratype WAM 02.353 (M88-3; P1. 3, figs 8-9), six costae occur on the earlier chambers, with an additional two short costae appearing on chamber no. 5, and dying out on chamber no. 6. This specimen has an extremely small initial chamber, followed by five chambers of expanding size. It appears to be a microspheric specimen. The wall structure of all specimens is thick and appears to be nonlamellar (see Pl. 3, fig. 10). The species has not been thin sectioned due to the low number of specimens.

Dimensions. Holotype F46840 (W49-3), length $420 \mu \mathrm{m}$, width approximately $120 \mu \mathrm{m}$, thickness approximately $110 \mu \mathrm{m}$. Paratype WAM 02.353 (M88-3), length $c .390 \mu \mathrm{m}$, width $120 \mu \mathrm{m}$, maximum thickness $95 \mu \mathrm{m}$.

Comparison with other species. Prodentalina septacosta n. sp. is similar to Dentalina tenuistriata Terquem (after KristanTollmann, 1964, pl. 14, figs 8-9), but in the present species the costae are thicker, parallel to the length of the test, and they disappear at the base of the final chamber.

Explanation of Plate 4.

figs 1, 2. Protonodosaria tereta (Crespin): 1, W349-5B, specimen lost, Hampton-1, $2169 \mathrm{~m}$, transmitted light, side view, $c . \times 250$, showing the thick sutures; 2, WAM 02.366 (W79-3), Hampton-1, 2240-2245 m, side view, $\times 225$; scale bar $100 \mu \mathrm{m}$ for figs 2 , 10. fig. 3. Pseudonodosaria wisemanae Heath \& Apthorpe, WAM 02.367 (W79-10), Hampton-1, $2169 \mathrm{~m}$, side view $\times 150$. figs 4, 5. Pseudonodosaria sp.: 4, apertural view; 5, side view, both $\times$ 150, of WAM 02.368 (W79-11), Hampton-1, 2169 m. figs 6-9. Lingulina borealis Tappan: 6, WAM 02.369 (M38-23), Hampton-1, SWC 2169 m; slightly oblique side view of large specimen, $\times 150$, to show median ridge on early chambers, slight median depression on last two chambers and slit of linguline aperture; 7, side view; and 8, apertural view of WAM 02.370 (W69-4), Hampton-1, 2240-2245 m, both $\times 150$; 9, transmitted light view, c. $\times 150$ of W349-48, Hampton-1, SWC $2169 \mathrm{~m}$ (specimen lost); scale bar $100 \mu \mathrm{m}$ for figs 3-9, 13. figs 10, 15. Frondicularia parri Crespin: 10, apertural view of broken specimen, $\times 225 ; 1$ 15, side view, $\times 75$; both of WAM 02.371 (W75-4), Hampton-1, 2290-2295 m. fig. 11. Frondicularia lambertensis Heath \& Apthorpe, WAM 02.372 (W79-14), Hampton-1, $2169 \mathrm{~m}$, transmitted light view showing chevron-shaped chambers and external evenly-spaced costae, side view, c. $\times 127$. figs 12, 13. Paralingulina tenera (Bornemann): 12, side view of WAM 02.373 (W69-10), Hampton-1, 2240-2245 m, $\times 100 ; 13$, side view of WAM 02.374 (M1-1), Hampton-1, $2169 \mathrm{~m}, \times 150$. fig. 14. Lingulina alaskensis Tappan, side view of WAM 02.375 (W78-18), Hampton-1, 2169 m, $\times 84$. figs 16, 17, 22-24. Lenticulina aff. varians (Bornemann): 16, apertural view; 17, side view of WAM 02.376 (W79-21), both Hampton-1, SWC 2169 m, $\times 150$; 22, edge view; and 23, side view of WAM 02.377 (M38-1), Hampton-1, 2270-2275 m, × 150; scale bar $100 \mu \mathrm{m}$ for figs 16-23, 25; 24, WAM 02.378 (W163-18), Hampton-1, 2290-2295 m, transmitted light view, $\times 195$, scale bar $100 \mu \mathrm{m}$. figs 18, 19. Marginulina sp. cf. M. eocomma (Kristan-Tollmann): 18, oblique apertural view; and 19, side view of WAM 02.379 (M38-16), Hampton-1, 2290-2295 m, $\times 150$; note the cribrate or modified radiate aperture in fig. 18. figs 20, 21. Marginulina sp.: 20, side view; and 21, edge view of WAM 02.380 (W69-1), Hampton-1, 2125-2130 m, $\times 150$. figs 25, 26. Palmula striata Heath \& Apthorpe: 25, side view of WAM 02.381 (W69-17), Hampton-1, 2200-2205 m, × 150; 26, transmitted light side view of WAM 02.382 (W349-55), Hampton-1, 2169 m, $c . \times 130$. 


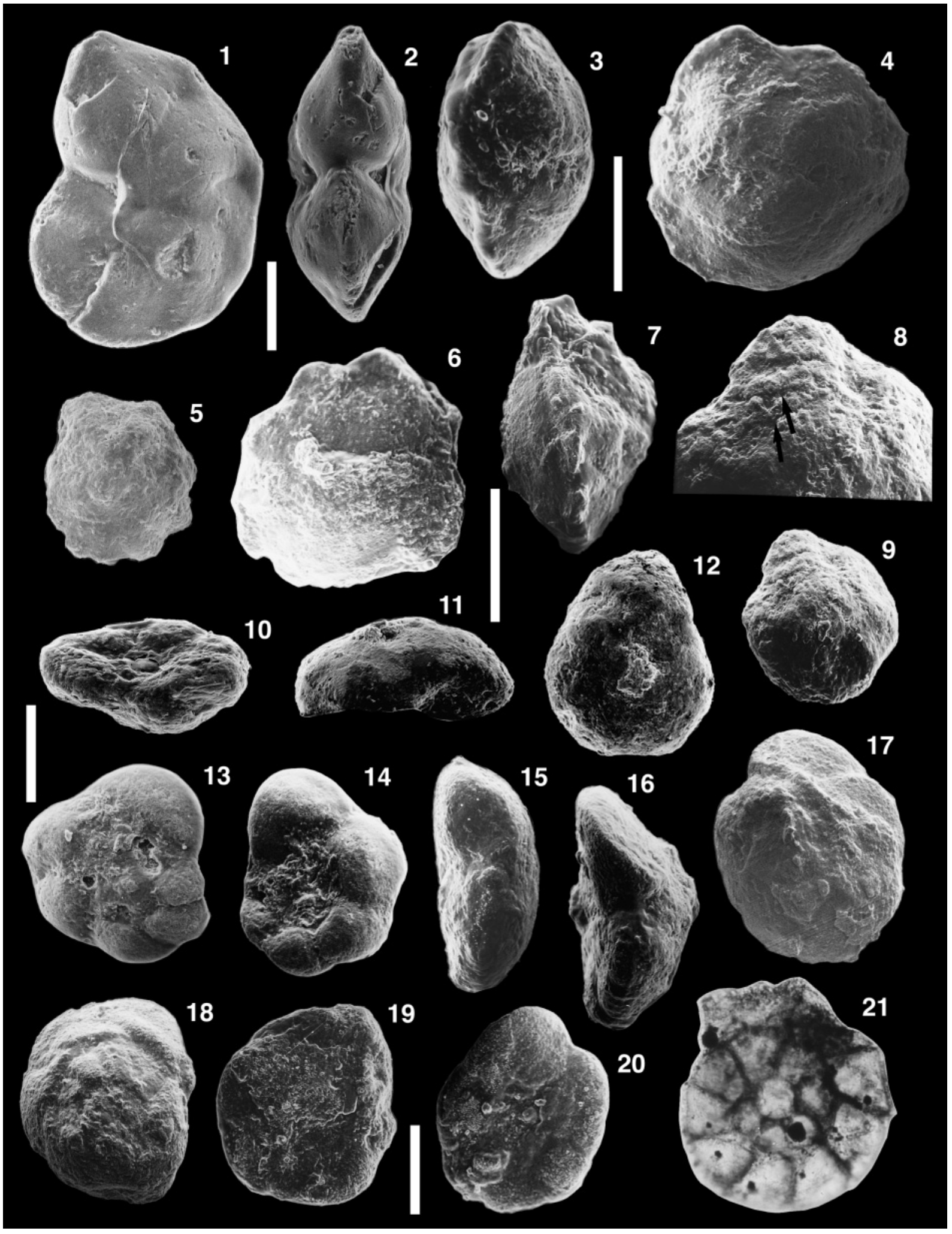


Remarks. This species is not placed in the genus Marginulina d'Orbigny because no indication of any initial coiling has been seen on the six specimens found thus far. The assignment to Prodentalina is tentative. Norling (1968) divided the genus Dentalina into three genera, on the basis of wall structure. Although this species has not been thin sectioned, due to the very small number of available specimens, the wall appears to be single-layered and nonlamellar when whole specimens are viewed in transmitted light. This suggests that this robust species should be placed within Norling's genus Prodentalina. Loeblich \& Tappan (1987, p. 391) state that the genus is unornamented. However, Norling in his description of the genus (1968, p. 34), only stated that the 'species hitherto examined lack ornamentation', which would not necessarily exclude ornamented species which in other characteristics fitted the generic diagnosis.

Genus Protonodosaria Gerke, 1959

Protonodosaria tereta (Crespin, 1958)

(Pl. 4, figs 1-2)

1958 Nodosaria tereta Crespin: 99, pl. 26, figs 1-4, pl. 31, figs 9, $10,12$.

1985 Protonodosaria tereta (Crespin); Palmieri in Foster et al.: 82-83, pl. 7, figs 1-10.

1994 Protonodosaria tereta (Crespin); Palmieri: 47, pl. 14, figs 10, 22, 26, pl. 15, fig. 15, pl. 26, figs 7a-b, pl. 30, fig. 4 .

Remarks. Sparse occurrences of a small, smooth-walled nodosarid with thick sutures, chambers wider than high, and a slightly more inflated final chamber, are referred to Crespin's Permian species.

Family Geinitzinidae Bozorgnia, 1973

(Following Palmieri (1994), Lunucammina is included in the Suborder Lagenina rather than in the Suborder Fusulinina.)

Genus Lunucammina Spandel, 1898

Lunucammina triangularis (Chapman \& Howchin, 1905) 1905 Geinitzina triangularis Chapman \& Howchin: 16, pl. 2, figs 9-10.

1958 Geinitzina triangularis Chapman \& Howchin; Crespin: 118-119, pl. 30, figs 8-11; pl. 31, fig. 7.
1985 Lunucammina triangularis Chapman \& Howchin; Palmieri, in Foster et al:: 83, pl. 8, figs 1-17.

1986 Lunucammina $\mathrm{cf}$. L. triangularis (Chapman \& Howchin); Heath \& Apthorpe: 332, pl. 8, figs 1-8.

1994 Lunucammina triangularis (Chapman \& Howchin 1905); Palmieri: 38, pl. 12, fig. 1, pl. 16, figs 1-20.

Remarks. A few specimens occur in Hampton-1, mainly at 2290-2295 m. They fall within the range of variation illustrated by Palmieri (1994, pl. 16) from the Permian, and correspond to specimens previously recorded from the Triassic by Heath \& Apthorpe (1986; see remarks therein).

?Family Nodosariidae Ehrenberg, 1838

[Smooth-walled 'Lingulina' spp. are tentatively placed here; their generic placement is uncertain (see 'Comparison with other species', for Lingulina borealis).]

Genus Lingulina d'Orbigny, 1826

Lingulina alaskensis Tappan, 1951 (Pl. 4, fig. 14)

1951a Lingulina alaskensis Tappan: 1, pl. 1, fig. 1a-b. 1951b Lingulina alaskensis Tappan: 13, pl. 4, figs 18-22. 1986 Pseudonodosaria sp.; Heath \& Apthorpe: 319, pl. 2, figs 21-23.

Remarks. Found as two specimens in Lawley-1 well, this smooth species with a quadrate profile also occurs as rare specimens in Hampton-1, where it is found spasmodically between $2169 \mathrm{~m}$ and $2310 \mathrm{~m}$.

Lingulina borealis Tappan, 1951

(P1. 4, figs 6-9)

1951b Lingulina borealis Tappan: 13, pl. 4, figs 5-8, 14-17. 1960 Lingulina klebelsbergi Oberhauser: 34, pl. 4, figs 8-20, 22.

1986 Lingulina borealis Tappan; Heath \& Apthorpe: 329-331, pl. 9, figs 1-23.

Remarks. Lingulina borealis is the most common species present in the Hampton-1 section, apart from the Krikoumbilica group. It ranges from $2125 \mathrm{~m}$ to $2345 \mathrm{~m}$, being mostly common (>20 specimens) in every sample; disappears over an interval of some $50 \mathrm{~m}$; then recurs rarely from $2425 \mathrm{~m}$ to $2470 \mathrm{~m}$.

Explanation of Plate 5.

figs 1, 2. Lenticulina sp. cf. L. polygonata Franke: 1, side; and 2, edge views of WAM 02.383 (M38-24), Hampton-1, SWC 2169 m, $\times 150$; scale bar $100 \mu \mathrm{m}$ for figs 1, 2, 5. figs 3-9. Duostomina cf. biconvexa Kristan-Tollmann: 3, edge; and 4, ventral/umbilical views of WAM 02.384 (W76-4), Hampton-1, 2150-2155 m, $\times 225 ; \mathbf{5}$, ventral/umbilical view of WAM 02.385 (W79-5), Hampton-1, 2305-2310 m, to show serrate outline; no aperture is visible, $\times 150 ; 6$, 7, WAM 02.385 (W79-5), Hampton-1, 2305-2310: 6, spiral view, with ridge of attached rock matrix across centre, $\times 225$; 7, edge view, to show acute margin and unevenly biconvex test, on poorly preserved but typical specimen, $\times 225 ; 8$, enlargement $\times 400$, showing faint suggestion of one or two apertural indentations on the face of the final chamber (arrowed); 9, ventral/umbilical view of whole specimen WAM 02.386 (W79-4), Hampton-1, 2305-2310 m, $\times 225$. Scale bar between figs 3 and 4 is $100 \mu \mathrm{m}$ for figs 3, 4, 6, 7, 9. figs 10, 13, 14. Oberhauserella ladinica (Oberhauser): 10, oblique edge view of WAM 02.387 (M38-13); 13, spiral; and 14, umbilical views of WAM 02.388 (W75-7), both from Hampton-1, 2290-2295 m; all $\times 170$; scale bar $100 \mu \mathrm{m}$. figs 11, 12, 15. Krikoumbilica sp., intermediate form between K. pileiformis He and K. compressa n. sp.: 11, slightly oblique edge view; and 12, spiral view of WAM 02.389 (M89-6), Hampton-1, 2190-2195 m, × 225; 15, edge view of WAM 02.390 (W76-6), Hampton-1, 2180-2185 m, × 225; figs 16-21. Krikoumbilica pileiformis He: 16, edge view showing gently concave umbilical surface; 17, spiral; and 20, umbilical views, all of WAM 02.391 (W69-9), Hampton-1, 2125-2130 m, all × 150; 18, spiral; and 19, umbilical views of WAM 02.392 (W75-9), Hampton-1, 2290-2295 m, $\times 150$; the umbilical area is partly obscured by rock matrix; scale bar for 11-12, 15-20 is 100 $\mu \mathrm{m}$; 21, transmitted light view from the spiral side of WAM 02.393 (W163-11), Hampton-1, 2290-2295 m, × 170; this view shows the short, moderately oblique sutures on the spiral side and the large proloculus, which is equal in size to the next four chambers in the whorl. 


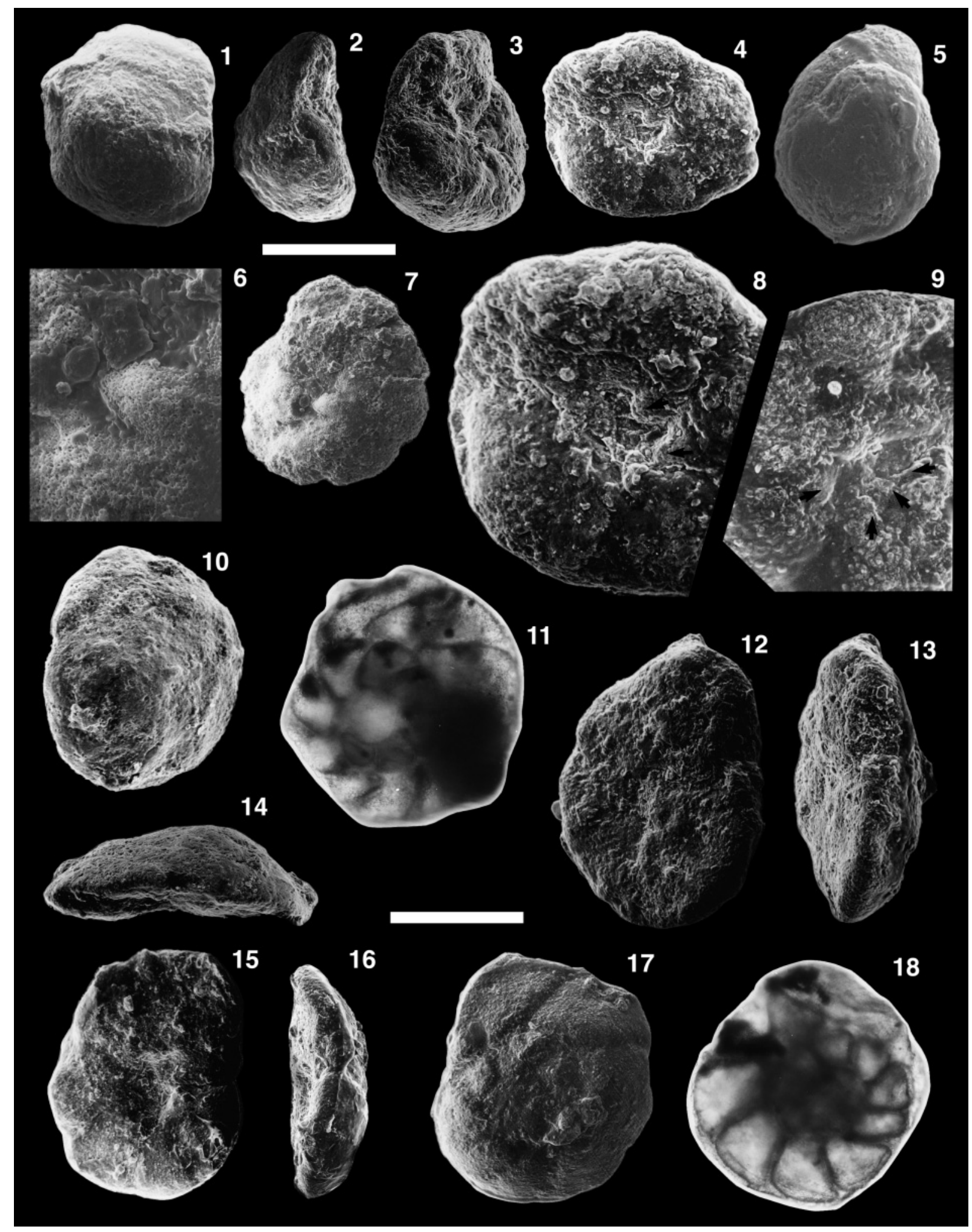


Comparison with other species. The smooth-walled Triassic ' $\mathrm{Lin}$ gulina' species $L$. borealis and L. alaskensis do not fit readily into any of the Palaeozoic genera proposed by Sellier de Civrieux \& Dessauvagie (1965). Pachyphloides of these authors (tentatively included under Cryptoseptida by Loeblich \& Tappan, 1987, p. 388) is superficially similar. However, Lingulina borealis differs from this genus in having a thin wall, apart from a single thickened median ridge. The aperture of Cryptoseptida (Loeblich \& Tappan, 1987, p. 388) is described as a small oval opening, which is very different from the complex, variable slit-and-lips character of the aperture of Lingulina borealis described by Heath \& Apthorpe (1986, pp. 329-331, pl. 9). From Frondina Sellier de Civrieux \& Dessauvagie, 1965, Lingulina borealis differs in its higher arched chambers, and in its complex, produced aperture. Lingulina borealis differs from Ichthyolaria Wedekind, 1937, in being less compressed, and in having lower-arched, less chevron-shaped chambers; in comparison to the other genera, in its lipped, produced aperture. Pending a detailed study of the Australian fauna in thin section, and clarification of the differences between the previously described genera, there seems little point in trying to force 'Lingulina' borealis into one of the above generic labels.

Lingulina australis Heath \& Apthorpe, 1986

1986 Lingulina australis Heath \& Apthorpe: 329, pl. 8, figs 9-20.

Remarks. This species occurs sporadically as single specimens in samples between $2125 \mathrm{~m}$ and $2345 \mathrm{~m}$ in Hampton-1. The specimens are poorly preserved, and the reader is referred to the original description and illustrations. The species should possibly be referred to Ichthyolaria, but requires thin section study to clarify its placement.

Genus Frondicularia Defrance, 1826

Frondicularia ingrami Heath \& Apthorpe, 1986

1986 Frondicularia ingrami Heath \& Apthorpe: 329, pl. 7, figs $18-26$.

1994 pars? Cryptoseptida caseyi (Crespin); Palmieri: 40, pl. 21, figs $13,14,16-20$ only.

Remarks. Occurs in small numbers between $2169 \mathrm{~m}$ and $2225 \mathrm{~m}$ in Hampton-1. Better-preserved and more numerous specimens occur in Lawley-1. As for the Lingulina species discussed above, the generic placement of this species requires further study.

Frondicularia limpida Crespin, 1958

1958 Frondicularia limpida Crespin: 112-113, pl. 29, figs 1-2.

1986 Frondicularia limpida Crespin; Heath \& Apthorpe: 325, pl. 7, figs 10-17.

1994 Ichthyolaria limpida (Crespin), part; Palmieri: 42, pl. 18, fig. 18 , pl. 19 , fig. 1 , pl. 27 , fig. 6 , pl. 30 , figs 16 , 18, pl. 31, figs 20 , 21.

Remarks. A smooth-walled, lanceolate species similar to $F$. ingrami. Found very rarely (as one or two specimens) in four samples from Hampton-1; much more common in Lawley-1. Other comments as for species above.

Frondicularia lambertensis Heath \& Apthorpe, 1986 (P1. 4, fig. 11)

1986 Frondicularia lambertensis Heath \& Apthorpe: 325, pl. 7, figs 3-9.

Remarks. Essentially only found in the sidewall core at $2169 \mathrm{~m}$.

\section{Frondicularia parri Crespin, 1945}

(Pl. 4, figs 10, 15)

1945 Frondicularia parri Crespin: 27, pl. 3, figs 9-11.

1958 Frondicularia parri Crespin; Crespin: 113, pl. 29, figs 3-7.

1961 Frondicularia subtilistriata Gerke: pl. 53, fig. 2.

1986 Frondicularia parri Crespin: Heath \& Apthorpe, 323, pl. 6, figs 14-20, pl. 7, figs 1-2.

1994 Howchinella parri (Crespin): Palmieri, 36, pl. 18, figs 14-15, 21, pl. 23, figs 9-10.

Frondicularia westraliensis Heath \& Apthorpe, 1986 1986 Frondicularia westraliensis Heath \& Apthorpe: 323, pl. 6, figs $1-8$.

Remarks. The three striate species of Frondicularia listed above (F. lambertensis, $F$. parri and $F$. westraliensis) occur sporadically in the Hampton-1 section (see Fig. 4, distribution chart). The generic assignment of these species is questionable. Loeblich \& Tappan (1987, p. 401) note that 'Upper Paleozoic to Lower

Explanation of Plate 6.

figs 1-9. Krikoumbilica pileiformis He: 1-4, 8, WAM 02.394 (W75-3), Hampton-1, 2290-2295 m - 1, spiral view; 2, edge view to show high conical shape; $\mathbf{3}$, oblique umbilical view to show depressed sutures on umbilical side; all $\times 225 ; \mathbf{4}, \mathbf{8}$, umbilical view to show deep open umbilicus with lobate folia projecting into it; $4 \times 225,8 \times 450$; 5, spiral view of WAM 02.395 (W75-5), Hampton-1, 2290-2295 m, $\times 225$; scale bar 100 $\mu$ m for figs 1-5, 7; 6, 7, WAM 02.396 (W77-25), Hampton-1, 2270-2275 m - 7, umbilical view of cleaned etched specimen; 6, higher magnification view of fig. 7, to show a single, lobate folium projecting into the umbilicus; other such chamber ends are either obscured or broken off; 9, WAM 02.397 (W76-15), Hampton-1, 2125-2130 m, view of part of the umbilicus to show an apparent series of overlapping folia in the umbilical hollow, $\times 300$. figs 10-18. Krikoumbilica compressa $\mathrm{n}$. sp.: 10, spiral view showing ovoid outline and swept-back later chambers; and 14, edge view to show compressed, concavo-convex profile, both of WAM 02.398 (M89-3), Hampton-1, 2290-2295 m, × 225; 11, transmitted light view of paratype WAM 02.399 (W163-5), Hampton-1, 2290-2295 m, viewed from the spiral side to show the elongated later chambers and highly oblique sutures which are characteristically bent backwards just above their junction with the spiral suture, $\times 195 ; \mathbf{1 2}$, 13, paratype WAM 02.400 (W75-16), Hampton-1, 2290-2295 m - 12, oblique umbilical view, with partly infilled umbilicus, $\times 225$; 13, edge view. The terminal face is somewhat damaged, but no clearly defined apertural structures are visible; scale bar $100 \mu \mathrm{m}$ for figs $10,12-17 ; \mathbf{1 5}$, umbilical view, showing open umbilicus with a suggestion of lobate folia projecting into it; 16, edge view, showing the highly compressed profile; 17, spiral view with unusually well-defined oblique sutures, showing the rapid enlargement of the last three chambers; all three are holotype WAM 02.401 (W69-5), Hampton-1, 2240-2245 m, × 225; 18, WAM 02.402 (W163-14), Hampton-1, 2290-2295 m, transmitted light view from umbilical side, to show that the sutures of the later chambers are more nearly radial on this side; $\times 180$. 


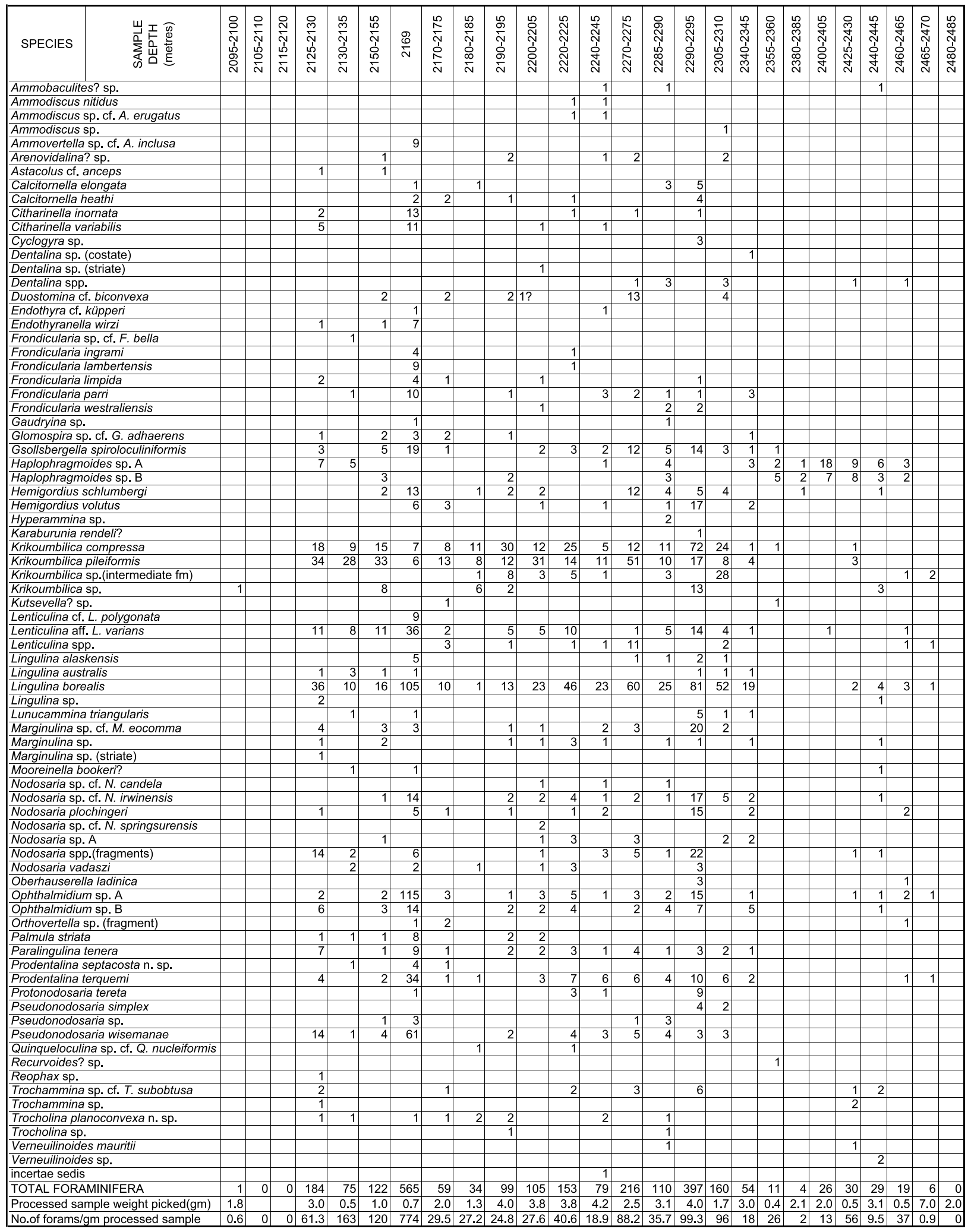

Fig. 4. Distribution chart of foraminifera in the Locker Shale, Hampton-1 well. 
Jurassic species previously included here [in Frondicularia] are referrable to genera of the Geinitzinidae and Ichthyolariidae'. On the basis of test shape, these species could be included in either Ichthyolaria Wedekind, or in Frondiculinita Gerke. On the basis of their variable radiate apertural shape, they could be included within Howchinella Palmieri, 1985.

Ichthyolaria is described as having a radial calcite wall, indistinct primary lamination, with no secondary lamination (Loeblich \& Tappan, 1987, pp. 389-390). Howchinella is described as having a double-layered wall with a thin inner organic layer and an outer calcite radial layer. Howchinella is described as being either without secondary lamination (as in Ichthyolaria), or as having partial secondary lamination (Palmieri, in Foster et al., 1985, p. 83). Palmieri considered Howchinella 'intermediate in the evolutionary trend linking Lunucammina to Ichthyolaria'. However, all three genera appear to co-exist in the Permian and Early to Middle Triassic. It is difficult to envisage why there should be a trend from an absence of secondary lamination (Lunucammina), through very variable degrees of secondary lamination (Howchinella), back to an absence of secondary lamination (Ichthyolaria). The alleged distinction between Ichthyolaria and Howchinella on the basis of wall structure does not appear to be borne out by thin sections figured by Palmieri (1994, pl. 27, figs 3-6), the structure of the wall appearing to be identical and without secondary lamination. Other thin sections (Palmieri, 1994, pl. 28, figs 4-5) show species of Howchinella with thick secondary lamination extending back over six to seven chambers of the test. Such differences suggest that Howchinella requires subdivision, or that some of its species should be assigned to other genera. A decision on where to place the present Triassic species will have to await not only a thin section study of those specimens, but also further study of the Permian species originally placed in Frondicularia, and now variously placed in Ichthyolaria and Howchinella by Palmieri (1994).

\section{Family Nodosariidae Ehrenberg, 1838 Genus Dentalina Risso, 1826 \\ Dentalina $\mathrm{sp}$ \\ (Pl. 3, figs 16-17)}

Remarks. A single broken, moderately large specimen was found at $2200-2205 \mathrm{~m}$. The test consists of $>3$ chambers in an arcuate series. The sutures are oblique. The aperture is produced and radiate. The surface is ornamented with numerous longitudinal fine costae, which cross the sutures and reach almost to the aperture. Between the costae there appear to be rows of minute pits.

\section{Genus Nodosaria Lamarck, 1812}

Nodosaria cf. irwinensis Howchin

(Pl. 3, figs 11-14)

1895 Nodosaria irwinensis Howchin: 196-197, pl. 10, figs 7-8. 1958 Nodosaria irwinensis Howchin; Crespin: 103, pl. 25, figs 4-8 only.

1985 part: Protonodosaria irwinensis (Howchin); Palmieri in Foster et al:: 82, pl. 7, figs 16-18 only.

1978 ?Nodosaria liratella Tappan; Hohenegger: fig. 2, fig. 7. non 1951b Nodosaria liratella Tappan n. sp.: 11, pl. 3, figs $17-20$.
Remarks. Very small, striate Nodosaria occur as fairly common but broken specimens in Hampton-1 between $2169 \mathrm{~m}$ and $2345 \mathrm{~m}$. They have not been thin sectioned, and therefore their generic placement, based on wall structure, is uncertain. Both Nodosaria and Protonodosaria are described by Loeblich \& Tappan (1987) as having a smooth surface, unlike the present species, which may possibly belong within Pyramidulina Fornasini.

The specific identification of the Hampton-1 specimens is also uncertain. Nodosaria irwinensis Howchin was described from the Lower Permian of Australia. Crespin (1958, p. 103) stated that the many specimens she had examined from the type locality (Fossil Cliff, Irwin River) are unlike those figured by Howchin. She further commented on the variable morphology of this species, and said that many of the specimens from the type locality may represent a new species. Palmieri (in Foster et al., 1985) figured six specimens from the type locality, which he considered to be 'average' for the population. They vary as to the coarseness of the ribbing, the specimens shown in SEM photographs (his pl. 7, figs 14, 19) having thicker, more closely spaced ribs than the Hampton-1 specimens figured here, but the light photographs (his pl. 7, figs 16, 17) having a close resemblance to the Hampton specimens. Tappan (1951b) described Nodosaria liratella from the Late Triassic Shublik Formation of Alaska as having 'about 10 low ribs'. The holotype has a more tapering test than the two figured paratypes. Hohenegger (1978) measured and figured 'Nodosaria liratella' from the Middle Triassic (Ladinian) of Austria. His specimens show 16-20 fine ribs, and in this respect are similar to the Hampton-1 specimens, which show $c .12-18$ ribs, which extend all the way to the aperture. The Hampton-1 specimens taper more than Hohenegger's specimens, but in this they resemble the holotype of Nodosaria liratella. It is possible that the Hampton-1 specimens represent a transitional form between the Permian Nodosaria irwinensis and the Ladinian 'Nodosaria liratella' of Hohenegger, but the differences, if any, between these forms appear to be very slight.

Nodosaria sp. cf. N. springsurensis Crespin, 1945

(Pl. 3, figs 20-21)

1945 Nodosaria springsurensis Crespin: 26, pl. 26, fig. 5.

1958 Nodosaria springsurensis Crespin; Crespin: 106, pl. 26, figs $11-12$.

Remarks. A few specimens with fewer and coarser ribs than the species above, are tentatively ascribed to $N$. cf. springsurensis.

Nodosaria sp. A

(Pl. 3, figs 18-19)

Remarks. This species has been found only as occasional incomplete specimens. The test of $>3$ chambers is almost parallelsided. The ornament consists of $c$. 18-20 fine ribs extending from the suture and covering the lower half of each chamber. The ribs die out upwards and the upper half of each chamber is smooth. The aperture is a central, circular, non-radiate opening. The wall microstructure is unknown.

The only similar species found in the literature is the Permian Nodosaria fisheri Crespin (1958), in which the fine ribs cover the sutures, and extend only a very small distance above and below each suture onto the chamber surface. The ornament thus appears to be distinctly different in its distribution from the Hampton-1 species. 
Nodosaria plochingeri (Oberhauser, 1960)

(P1. 3, figs 22, 24-26)

1960 Pseudoglandulina plochingeri Oberhauser: 27, pl. 1, figs $1-41$.

1986 Nodosaria plochingeri (Oberhauser); Heath \& Apthorpe: 317-318, pl. 1, figs 15-16.

Remarks. This species is much more prominent in Hampton-1 than in Lawley-1, occurring erratically, and sometimes in moderate numbers, from $2125 \mathrm{~m}$ to $2465 \mathrm{~m}$. The specimens found vary from a pronounced flaring shape (Pl. 3, fig. 25) to parallelsided forms (Pl. 3, fig. 24). The prominent irregular longitudinal ridges are as figured by Oberhauser (1960). In the SEM, some Hampton-1 specimens show a faint longitudinal striation on the surface between the ribs (Pl. 3, figs 24-25).

\section{Nodosaria vadaszi (Oberhauser, 1960)}

(Pl. 3, fig. 23)

1960 Dentalina vadaszi Oberhauser: 23, pl. 3, figs 11, 17, pl. 4, fig. 34.

1986 Nodosaria vadaszi (Oberhauser); Heath \& Apthorpe: 319, pl. 1, figs $17-18$.

Remarks. Recorded as occasional specimens between $2130 \mathrm{~m}$ and $2295 \mathrm{~m}$ in Hampton-1.

Genus Pseudonodosaria Boomgaart, 1949
Pseudonodosaria $\mathrm{sp}$.

(Pl. 4, figs 4-5)

Remarks. A few small globular specimens found between $2169 \mathrm{~m}$ and $2310 \mathrm{~m}$ are referred to this genus.

\section{Pseudonodosaria wisemanae Heath \& Apthorpe, 1986}

(P1. 4, fig. 3)

1986 Pseudonodosaria wisemanae Heath \& Apthorpe: 319-320, pl. 2, figs 1-20.

Remarks. This species is abundant in the sample at $2169 \mathrm{~m}$, and occurs in small numbers from $2125 \mathrm{~m}$ to $2310 \mathrm{~m}$. The specimens are poorly preserved in comparison to the well-preserved type material. The distinctive ornament of fine longitudinal furrows containing rows of perforations is visible on only some of the chambers, due to poor preservation.

Family Vaginulinidae Reuss, 1860

Genus Lenticulina Lamarck, 1804

Lenticulina sp. cf. L. polygonata Franke, 1936

(Pl. 5, figs 1-2)

?1936 Lenticulina polygonata Franke: 118, pl. 12, fig.1. 1960 Lenticulina polygonata Franke; Oberhauser: 20, pl. 2, figs $18-19,27$.

Remarks. Nine specimens of a Lenticulina with slightly compressed, polygonal outline, and $0.35 \mathrm{~mm}$ in maximum diameter, were found in Hampton-1. The chambers are moderately inflated, the sutures curved and depressed, the umbilicus deep, and the aperture slightly produced. There are seven or eight chambers in the final whorl. These specimens appear to be similar in size and shape to specimens figured by Oberhauser (1960) from the Carnian of the Alps. He noted that his specimens were smaller than the Jurassic $L$. polygonata described by Franke, which has a maximum diameter of $0.75 \mathrm{~mm}$. The Triassic form may be a separate sub-species.

Lenticulina aff. varians (Bornemann, 1854)

(Pl. 4, figs 16-17, 22-24)

1854 Cristellaria varians Bornemann: 41, pl. 4, figs 32-34.

1936 Cristellaria (Lenticulina) varians Bornemann; Franke: 112, pl. 11, figs 9-13.

1960 Lenticulina aff. varians (Bornemann); Oberhauser: 20, pl. 2, figs 3-6.

1986 Lenticulina varians (Bornemann); Heath \& Apthorpe: 321, pl. 5, fig. 13 .

Remarks. Highly compressed and variable specimens of Lenticulina occur in two intervals of the Hampton-1 sequence: $2169 \mathrm{~m}$ to $2225 \mathrm{~m}$, and $2290 \mathrm{~m}$ to $2360 \mathrm{~m}$. Most appear to fit within $L$. varians. The more strongly uncoiled varieties appear to fall within Marginulina aff. vetusta (d'Orbigny) of Oberhauser (1960, pl. 2, figs 1,2) or within Lenticulina (Vaginulinopsis) sp. A of Kristan-Tollmann (1964, pl. 26, figs 7, 9). The group has not been studied in detail in Hampton-1.

Genus Palmula Lea, 1833

Palmula striata Heath \& Apthorpe, 1986

(P1. 4, figs 25-26)

1986 Palmula striata Heath \& Apthorpe: 321-323, pl. 2, figs $7-11$.

Remarks. Occurs in small numbers as broken specimens between $2125 \mathrm{~m}$ and $2205 \mathrm{~m}$ in Hampton-1.

Genus Marginulina d'Orbigny, 1826

Marginulina sp.

(Pl. 4, figs 20-21)

Remarks. A single broken specimen, moderately compressed, with an apparent small initial coil, and a surface ornamented with linear grooves on both sides of the test, was found at 2125-2130 m in Hampton-1.

\section{Marginulina sp. cf. M. eocomma (Kristan-Tollmann)} (Pl. 4, figs 18-19)

1983 Lenticulina eocomma Kristan-Tollmann; KristanTollmann, abb. 3, figs 1, 11, pl. 3, fig. 1 .

1986 Marginulina sp.; Heath \& Apthorpe: 325, pl. 5, figs $14-15$.

Remarks. Small specimens of a Marginulina with a rounded margin, becoming almost round in cross-section in the final chamber, occur sparsely in Hampton-1 between $2125 \mathrm{~m}$ and $2310 \mathrm{~m}$. The test consists of about 4-5 chambers, the first three in a partial coil, then uncoiling. The aperture appears to consist of a small central hole, surrounded by about seven other small 
holes, approaching a cribrate condition. A specimen of very similar form found in Lawley-1 well had the final wall broken away, revealing a mould of a radiate aperture. The aperture on the figured Hampton-1 specimen (Pl. 4, fig. 18) may be an 'overgrown' radiate aperture.

This species differs from Lenticulina eocomma KristanTollmann by having sutures which are not depressed but are flush with the surface. The initial coil may be better developed in the present species. The specimens may represent a new species but require further study.

Genus Citharinella Marie, 1938

Citharinella inornata Heath \& Apthorpe, 1986

1986 Citharinella inornata Heath \& Apthorpe: 321, pl. 3, figs $1-3$, pl. 4, figs 1-3.

Citharinella variabilis Heath \& Apthorpe, 1986 1986 Citharinella variabilis Heath \& Apthorpe: 321, pl. 3, figs 4-6, pl. 4, figs 4-7, pl. 5, figs 1-6.

Remarks. A small number of both species of Citharinella, previously described from the Lawley-1 well, were found in Hampton-1. One of the Hampton-1 specimens shows a welldeveloped radiate aperture. Apart from this, the poorly preserved specimens do not add any additional information to the previous record, and as both species have been extensively illustrated in Heath \& Apthorpe (1986), they are not figured here.

Suborder Robertinina Loeblich \& Tappan, 1984 Family Duostominidae Brotzen, 1963

Genus Duostomina Kristan-Tollmann, 1960

Duostomina cf. biconvexa Kristan-Tollmann, 1960

(Pl. 5, figs 3-9)

1960 Duostomina biconvexa Kristan-Tollmann: 68, pl. 17, figs $1-2$, pl. 18, fig. 2.

Remarks. Specimens are small, and rare except at 2270-2275 m, where they are sparse. The double aperture described as a characteristic of this genus could not be seen with any certainty. Many specimens have a distinctive stellate chamber outline, but apart from this no features could be clearly discerned due to poor preservation.

Family Oberhauserellidae Fuchs, 1970

Genus Krikoumbilica He, 1984

Krikoumbilica compressa sp. nov. (Pl. 6, figs 10-18)

Derivation of name. From the Latin compressio, a pressing together, a compression; referring to the flattened spire and very compressed margin.

Diagnosis. A very compressed, low-spired species of Krikoumbilica with oblique, swept-back chambers.

Holotype. WAM 02.401 (W69-5), Hampton-1 well, 22402245 m: Pl. 6, figs 15-17.
Paratypes. WAM 02.400 (W75-16), Hampton-1, 2290-2295 m: Pl. 6, figs 12-13; WAM 02.399 (W163-5), Hampton-1, 22902295 m: Pl. 6, fig.11; WAM 02.398 (M89-3), Hampton-1, 22902295 m: Pl. 6, figs 10, 14.

Repository of type specimens. Western Australian Museum, Francis St, Perth, Western Australia.

Material. 262 specimens.

Age. Spathian to Anisian.

Description. Test planoconvex to concavo-convex, a very low, flattened trochospire. Outline oval to rounded, chambers very weakly lobulate. Periphery compressed to very narrowly rounded. Chambers arranged in two whorls; six to eight chambers in the final whorl, enlarging slowly; the last two chambers enlarging more rapidly to produce an ovate outline. The chambers on the spiral side are elongated backward in the direction of coiling. Sutures usually flush with surface; on the spiral side, straight to gently curved and directed obliquely backward; on the umbilical side, radial. Because of the different shape of the chamber surface on the spiral and umbilical sides, the intercameral wall must be curved and slightly twisted (as is suggested by the shadowy spiral end of this wall seen in transmitted light in Pl. 6, fig. 18). The umbilical depression is shallow and of moderate width, occupying about a quarter of the diameter of the test; in most specimens it is filled with rock matrix. In those specimens with an open umbilicus, the chamber ends (folia) protrude into the umbilical hollow, making the margin of the umbilical area appear weakly lobulate, as in Oberhauserella. There are no indications of lobed or crenulate sutures on the umbilical side. Under the light microscope, no aperture of any kind is visible. SEM examination suggests the presence of a thin slit on the final chamber, terminating in a small rounded peripheral opening, but this could be an artefact of preservation. It is possible that the aperture is underneath the final lobate folium in the umbilicus. The wall is calcareous; all specimens appear to be recrystallized; microstructure is unknown. The wall originally may have been aragonitic, as the specimens are more recrystallized than other calcareous genera in the same samples. Some specimens retain a well-defined brown organic inner lining within the chambers, particularly the earlier chambers, but sometimes extending to the latest. In other specimens this lining does not appear to be preserved.

Dimensions. Holotype - WAM 02.401 (W69-5), maximum diameter $0.187 \mathrm{~mm}$, thickness $0.055 \mathrm{~mm}$; paratype - WAM 02.400 (W75-16), maximum diameter $0.210 \mathrm{~mm}$, thickness $c .0 .055 \mathrm{~mm}$; paratype - WAM 02.399 (W163-5), maximum diameter $0.23 \mathrm{~mm}$; paratype - WAM 02.398 (M89-3), maximum diameter $0.187 \mathrm{~mm}$, thickness $0.07 \mathrm{~mm}$. Maximum diameter of specimens ranges from $0.130 \mathrm{~mm}$ to $0.230 \mathrm{~mm}$.

Occurrence. Hampton-1 well, $2169 \mathrm{~m}$ (sidewall core) and all samples from $2125-2130 \mathrm{~m}$ to $2305-2310 \mathrm{~m}$ (ditch cutting samples): common; single specimen occurrences down to $2425-$ $2430 \mathrm{~m}$. 
Comparison with other species. The present species is placed in the genus Krikoumbilica on the basis of its compressed margin (rather than the rounded margin of Oberhauserella); the presence of 8-9 chambers in the final whorl (compared with 4-5 in Oberhauserella); and on the character of the umbilical area. In this respect the description of the type species of Krikoumbilica ( $K$. pileiformis $\mathrm{He}$ ) is incomplete. Although prominent umbilical folia are shown protruding from the ends of chambers in He's figures (1984, fig. 2, p. 426, and pl. II, fig. 10c), no mention is made of these in the description.

Krikoumbilica compressa is thought to be related to the Ladinian species Kollmannita gemmaeformis Fuchs. From the latter species Krikoumbilica compressa may be distinguished by its more compressed, concavo-convex test, larger number of chambers in the final whorl, simple lobulate umbilicus, lack of double apertural depressions in the final chamber, and apparent absence of an umbilical plug. Fuchs (1967) described three species of Kollmannita as having an umbilical plug.

Discussion of generic classification. As mentioned above, Krikoumbilica appears very similar to the genus Kollmannita of Fuchs (1967). Kristan-Tollmann (1983) stated that the genus Kollmannita was invalid. She assigned its genotype, Globigerina ladinica Oberhauser, to Fuchs' genus Oberhauserella, and assigned most of the other species of Kollmannita to Diplotremina. Globigerina (Kollmannita) ladinica, with its gently rounded margin, few chambers and non-fimbriate umbilicus, is probably best transferred to Oberhauserella, as Kristan-Tollmann suggested. Two other species of Kollmannita, K. diplotreminaeformis Fuchs and $K$. multiloculata Fuchs, are biconvex forms with a fimbriate umbilicus. There may be justification for including these in Diplotremina. This leaves several species of Kollmannita, specifically $K$. gemmaeformis Fuchs, $K$. praeladinica Fuchs and $K$. cordevolica Fuchs, without a suitable generic label. All are concavo-convex forms with compressed chambers, narrowly rounded margins and a relatively simple umbilical area with extended, slightly thickened chamber ends which protrude into the umbilicus. $K$. gemmaeformis and $K$. praeladinica have weakly crenulated sutures, according to Fuchs, but do not approach the complexity of the sutures and umbilical margin of Diplotremina. There seems some merit in retaining Kollmannita as the name for these concavo-convex species, but a new genotype would be required. Alternatively these three species could be reassigned to the genus Krikoumbilica He. Loeblich \& Tappan (1987, p. 439) listed Kollmannita as a synonym of Oberhauserella, but the non-inflated shape of the chambers of all species of Kollmannita (except the genotype, $K$. ladinica) does not agree with their description of Oberhauserella. The present species is placed provisionally in Krikoumbilica.

Discussion of the Suborder classification of Krikoumbilica. The preservation of almost all specimens of Krikoumbilica is very poor, and worse than that of other calcareous genera in the same samples. This prompts the speculation that the wall structure may originally have been aragonitic. This in turn suggests a possible relationship with the Jurassic genus Reinholdella. However, S. Revets (pers. comm.) has expressed the contrary opinion that the specimens of Krikoumbilica are no worse in preservation than the remainder of the assemblage, given that the remainder consists of miliolids and mainly smooth-walled 'nodosarids'. The latter group, he comments, are always better preserved than other calcareous foraminifera, in samples where preservation is poor. Hence, he sees no necessity for Krikoumbilica to have had an originally aragonitic wall and suggests that it may have always been of calcite. This, in turn, would remove Krikoumbilica from the Robertinina and place it within the Rotaliina, as the ancestral form for all trochospirally coiled rotaliid genera. The presence of umbilical flaps, particularly in $K$. pileiformis, lends support to this radical suggestion. The material requires further study to investigate this hypothesis.

\section{Krikoumbilica pileiformis $\mathrm{He}, 1984$}

(Pl. 5, figs 16-21; Pl. 6, figs 1-9)

1984 Krikoumbilica pileiformis He: 426, text-fig. 2, 430 (in English), pl. 2, figs 9a-c, 10a-c (holotype), 12, 13, pl. 4, figs $8-11$.

Description. Test of medium size; a planoconvex, moderately high trochospire. On the spiral side, all chambers are indistinctly visible; chambers slowly enlarge in about 2.5 whorls. The chamber height in a radial direction is low relative to width (in the direction of coiling). Eight chambers are present in the final whorl; chambers are weakly lobulate, test outline circular. Sutures on the spiral side are generally flush with the surface (Pl. 6, fig. 5), although a few specimens have depressed sutures (Pl. 5, figs 17,18 ) which, in the case of fig. 18 , may be due to preservation as an internal mould. The sutures are directed slightly backwards, but are shorter than in $K$. compressa n. sp., described above, and the chambers are not strongly elongated in the direction of coiling as they are in $K$. compressa. The flat or weakly concave umbilical side has (in the better preserved specimens) a wide, deep umbilicus, occupying about one third of the diameter of the specimen. Lobate chamber ends (folia) protrude into the deep umbilicus ( $\mathrm{Pl}$. 6, figs 3, 4, 6, 8, 9). There is no indication of a crenulated or fimbriate outline to the umbilicus or along the sutures. These latter characteristics suggest that Krikoumbilica is closely related to Oberhauserella, and exclude it from the genus Diplotremina Kristan-Tollmann, 1960. There is some indication seen in one transmitted light photo that the aperture opened into the umbilicus underneath the lobate folia (flap-like extensions of the chambers). The wall is calcareous; microstructure unknown. Almost all specimens appear to be recrystallized, with little or no internal structure, suggesting the possibility of an aragonitic wall composition. A few specimens contain brown organic linings in the chambers, as in $K$. compressa, and have the internal chamber structure intact.

Comparison with other species. Krikoumbilica pileiformis as identified in this material resembles the specimen figured by $\mathrm{He}$ (1984, pl. 2, fig. 9a-c), but most specimens seen here have a higher, more conical shape than the holotype (He, pl. 2, fig. 10a-c). Krikoumbilica pileiformis differs from Oberhauserella alta Fuchs in the much greater number of chambers in the test. From $O$. norica Fuchs and $O$. quadrilobata Fuchs, Krikoumbilica pileiformis differs in its more conical shape, the greater number of its chambers, and its less lobulate outline. From O. rhaetica 
(Kristan-Tollmann), O. parviforamen Fuchs and O. margaritifera Kristan-Tollmann (which are all very similar in having a highly inflated chamber shape and rapidly enlarging chambers), Krikoumbilica pileiformis differs completely in its non-inflated and very slowly enlarging chambers, which are low relative to width, and in its moderately high trochospiral test. From the high-spired genera Schlagerina Fuchs and Praegubkinella Fuchs (placed in synonymy with Oberhauserella by Loeblich \& Tappan, 1987, p. 439), this species differs in its conical rather than rounded test, flatter umbilical side and its wide, open umbilical region.

Occurrence. Krikoumbilica pileiformis was described from the Anisian and Ladinian of Guizhou province, South China, by $\mathrm{He}$ (1984). The Hampton material described here is the only other occurrence known to the author. In Hampton-1 it ranges from $2125-2130 \mathrm{~m}$ to $2430-2435 \mathrm{~m}$ (sparse to common), and occurs as three specimens at 2425-2430 m.

Palaeoecology. In the present material, Krikoumbilica pileiformis has been found only in association with Krikoumbilica compressa n. sp., and with a number of indeterminate recrystallized specimens referred to Krikoumbilica sp., all of which appear to be closely related. The abundance of the genus Krikoumbilica in Hampton-l well between $2180 \mathrm{~m}$ and $2310 \mathrm{~m}$, and its absence from the nearby Lawley-1 well, suggests that the genus preferred an open marine habitat on the continental shelf. In the Hampton-1 well, the specimen numbers of Krikoumbilica fluctuate from one sample to another, presumably in response to the availability of suitable substrate. One specimen has a prominent groove on the umbilical side, which might reflect attachment to an algal stem, and the flat umbilical surface of Krikoumbilica suggests analogies with modern epifaunal genera such as Neoconorbina. Fuchs (1967) suggested that coiled genera, including Oberhauserella, Schlagerina and Praegubkinella, were the ancestors of the Jurassic plankton, and may themselves have had a planktonic mode of life. The Hampton material seems neither to confirm nor contradict such a hypothesis.

\section{Krikoumbilica $\mathrm{sp}$. \\ (P1. 5, figs 11-12, 15)}

Remarks. A number of specimens were found which appear intermediate between Krikoumbilica compressa n. sp. and $K$. pileiformis $\mathrm{He}$. The later chambers on the spiral side are elongated, but to a lesser extent than in $K$. compressa. The spiral side is gently convex, without the prominent apex seen in $K$. pileiformis. The periphery varies but tends to be more gently rounded than in either $K$. pileiformis or $K$. compressa. Further study of these forms is required to decide whether they form a separate species.

Genus Oberhauserella Fuchs, 1967

Oberhauserella ladinica (Oberhauser)

(Pl. 5, figs 10, 13-14)

1960 Globigerina ladinica Oberhauser: 43, pl. 5, figs 12, 14, 16. 1967 Kollmannita ladinica (Oberhauser); Fuchs: 144, pl. 2, figs 4-6, pl. 3, fig. 2.
Remarks. Single specimens occur in the Hampton-1 sequence at $2180-2185 \mathrm{~m}$ and $2290-2295 \mathrm{~m}$. They appear typical for the species, which was described from the Ladinian of Austria.

\section{ACKNOWLEDGEMENTS}

I thank Prof. David Haig for critically reading the manuscript, for discussions on the Permian links with the fauna, and for his helpful comments and suggestions. Woodside Offshore Petroleum Pty Ltd (now Woodside Energy Ltd) is thanked for supporting the early part of this study whilst the author was in its employ, for provision of desktop scanning electron microscope facilities, and for permission to use unpublished palynological data on the Hampton-1 well. Dr Stefan Revets is thanked for taxonomic discussions. The Department of Geology and Geophysics, University of Western Australia, is thanked for the provision of scanning electron microscope and photographic facilities. Ken Apthorpe kindly drafted Figures 1 and 3 .

\section{Manuscript received 29 March 2001 Manuscript accepted 10 November 2002}

\section{REFERENCES}

BMR Palaeogeographic Group 1990. Australia - evolution of a continent. Australia, Bureau of Mineral Resources, Geology and Geophysics.

Balme, B.E. 1969. The Triassic system in Western Australia. APEA Journal, 9(2): 67-78.

Balme, B.E. 1990. Australian Phanerozoic timescales: 7. Triassic. Biostratigraphic charts and explanatory notes. Australia, Bureau of Mineral Resources, Geology and Geophysics, Record, 1989/37.

Benjamini, C. 1984. Foraminifera from the Ra' af Formation (Anisian), Har 'Areif, western Negev, Israel. Benthos '83; 2nd International Symposium on Benthic Foraminifera (Pau, April 1983): 35-40.

BOC of Australia Ltd. 1974. Hampton-1 Well Completion Report. (Unpublished open file report, Dept. of Minerals and Energy, Perth, Western Australia).

Bornemann, J.G. 1854. Über die Liasformation in der Umgegend von Göttingen. Inaugural Dissertation: 26-45.

Chapman, F. \& Howchin, W. 1905. A monograph of the Foraminifera of the Permo-Carboniferous limestone of New South Wales. Geological Survey of New South Wales, Palaeontological Memoir, 14: $1-22$.

Crespin, I. 1945. Some Permian Foraminifera from eastern Australia. Proceedings Royal Society of Queensland, 56(3): 23-30.

Crespin, I. 1958. Permian foraminifera of Australia. Australia, Bureau of Mineral Resources, Bulletin, 48: 207pp.

Crespin, I. 1963. Lower Cretaceous arenaceous foraminifera of Australia. Australia, Bureau of Mineral Resources, Bulletin, 66: 1-110. Cushman, J.A. \& Waters, J.A. 1927. Arenaceous Paleozoic Foraminifera from Texas. Contributions from the Cushman Foundation for Foraminiferal Research, 3(3): 146-153.

Cushman, J.A. \& Waters, J.A. 1928. Some Foraminifera from the Pennsylvanian and Permian of Texas. Contributions from the Cushman Foundation for Foraminiferal Research, 4(2): 31-55.

Ellis, B.F. \& Messina, A. 1940 et seq. Catalogue of Foraminifera. American Museum of Natural History, New York.

Foster, C.B., Palmieri, V. \& Fleming, J.G. 1985. Plant microfossils, Foraminiferida, and Ostracoda, from the Fossil Cliff Formation (Early Permian, Sakmarian), Perth Basin, Western Australia. In: Lindsay, J.M. (Ed.), Stratigraphy, Palaeontology, Malacology. Department of Mines and Energy South Australia, Special Publication, 5: $61-105$.

Franke, A. 1936. Die Foraminiferen des deutschen Lias. Preussischen Geologischen Landesanstalt, Berlin: 1-138. 
Fuchs, W. 1967. Über Ursprung und Phylogenie der Trias'Globigerinen' und die Bedeutung dieses Formenkreises für das echte Plankton. Verhandlungen der Geologischen Bundesanstalt (Wien), 1/2: $135-176$.

Gerke, A.A. 1961. Foraminifery Perskikh, Triasovykh i Leyasovykh otlozheniy neftenosnykh rayonov severa tsentral'noy Sibiri. Trudy Nauchno-Issledovatelskii Institut Geologii Arktiki, 120: 1-518.

Goel, R.K., Zaninetti, L. \& Srivastava, S.S. 1981. Les foraminiferès de l'Anisien (Trias Moyen) de la localite de Guling, Vallee de Spiti (Himalaya, Inde Septentrionale). Archives Science Genève, 34(2): 227-234.

Gorter, J.D. 1994. Triassic sequence stratigraphy of the Carnarvon Basin, Western Australia. In: Purcell, P.G. \& Purcell, R.R. (Eds), The Sedimentary Basins of Western Australia: Proceedings of Petroleum Exploration Society of Australia Symposium, Perth, 1994: 397-413.

Gorter, J.D., Ziolkowski, V. \& Bayford, S.W. 1998. Evidence of Lower Triassic reservoirs with possible hydrocarbon charge in the Southern Bonaparte Basin. In: Purcell, P.G. \& Purcell, R.R. (Eds), The Sedimentary Basins of Western Australia 2: Proceedings of Petroleum Exploration Society of Australia Symposium, Perth, 1998: 229-235.

Gradstein, F.M. 1983. Paleoecology and stratigraphy of Jurassic abyssal foraminifera in the Blake-Bahama Basin, Deep Sea Drilling Project Site 534. In: Sheridan, R.E., Gradstein, F.M. et al. (Eds), Initial Reports of the Deep Sea Drilling Project, LXXVI, US Government Printing Office, Washington, 537-559.

Haig, D.W. 1979a. Jurassic foraminiferids from the Western Highlands of Papua New Guinea. Neues Jahrbuch für Geologie und Paläontologie Monatshefte, 4: 208-215.

Haig, D.W. 1979b. Global distribution patterns for mid-Cretaceous foraminiferids. Journal of Foraminiferal Research, 9(1): 29-40.

Haig, D.W. 1980. Early Cretaceous Textulariine foraminiferids from Queensland. Palaeontographica, Abt. A, 170: 87-138.

Haq, B.U., Hardenbol, J. \& Vail, P.R. 1987. Chronology of Fluctuating Sea Levels Since the Triassic. Science, 235: 1156-1167.

Haq, B.U., Hardenbol, J. \& Vail, P.R. 1988. Mesozoic and Cenozoic chronostratigraphy and cycles of sea-level change. In: Wilgus, C.K. et al. (Eds), Sea-Level Changes: an Integrated Approach. Society of Economic Paleontologists and Mineralogists, Special Publication, 42: 71-108.

He, Y. 1984. Middle Triassic foraminifera from central and southern Guizhou, China. Acta Palaeontologica Sinica, 23(4): 420-431.

Heath, R.S. \& Apthorpe, M. 1986. Middle and Early(?) Triassic foraminifera from the Northwest Shelf, Western Australia. Journal of Foraminiferal Research, 16(4): 313-333.

Helby, R.J., Morgan, R. \& Partridge, A.D. 1987. A palynological zonation of the Australian Mesozoic. Association of Australasian Palaeontologists, Memoir, 4: 1-94.

Hocking, R.M., Moors, H.T., Van De Graaff, W.J.E. (with Allen, A.D., Apthorpe, M.C., Harrison, H., Heath, R.S., Smith, D.N. \& Tait, A.M.) 1987. Geology of the Carnarvon Basin, Western Australia. Geological Survey of Western Australia, Bulletin, 133 $1-289$.

Hohennegger, J. 1978. Populationsgenetische Deutung des morphologischen Wandels der triassischen Foraminifere Nodosaria striatoclavata. Lethaia, 11: 199-215.

Howchin, W. 1895. Carboniferous Foraminifera of Western Australia with descriptions of new species. Transactions of the Royal Society of South Australia, 19: 194-198.

Jones, D.K. 1967. Onslow No. 1 well, Western Australia, Well Completion Report. West Australian Petroleum Pty Ltd report (unpublished open file report).

Koehn-Zaninetti, L. 1968. Les Foraminifères du Trias de la région de l'Almtal (Haute-Autriche). [Text condensed from thesis No. 1467], 14, Médecine et Hygiène. Genève.

Koehn-Zaninetti, L. 1969. Les Foraminifères du Trias de la région de l'Almtal (Haute-Autriche). Jahrbuch der Geologischen Bundesanstalt, Sonderband, 14: 1-155.

Kristan-Tollmann, E. 1960. Rotaliidea (Foraminifera) aus der Trias der Ostalpen. Jahrbuch der Geologischen Bundesanstalt A, Sonderband, 5 47-78.
Kristan-Tollmann, E. 1964. Die Foraminiferen aus den rhätischen Zlambachmergeln der Fischerwiese bei Aussee im Salzkammergut. Jahrbuch der Geologischen Bundesanstalt A., Sonderband, 10: $1-189$.

Kristan-Tollmann, E. 1983. Foraminiferen aus dem Oberanis von Leidapo bei Guiyang in Südchina. Mitteilungen der Österreichischen Geologischen Gesellschaft, 76: 289-323.

Kristan-Tollmann, E. 1988. A comparison of Late Triassic agglutinated foraminifera of Western and Eastern Tethys. In: Gradstein, F.M. \& Rögl, F. (Eds), Second International Workshop on Agglutinated Foraminifera. Abhandlungen der Geologischen Bundesanstalt, 41: 245-253.

Langer, W. 1968. Neue Miliolacea (Foram.) aus der mittleren Trias Kleinasiens. Senckenbergiana Lethaea, 49(5/6): 587-593.

Loeblich, A.R. Jr \& Tappan, H. 1987. Foraminiferal genera and their classification. Van Nostrand Reinhold, New York, 970+212pp.

Ludbrook, N.H. 1967. Permian deposits of South Australia and their fauna. Transactions of the Royal Society of South Australia, Adelaide, 91: $65-87$.

McTavish, R.A. 1973. Triassic Conodont Faunas from Western Australia. Neues Jahrbuch für Geologie und Paläontologie Abhandlungen, 143(3): 275-303.

Nagy, J. 1992. Environmental significance of foraminiferal morphogroups in Jurassic North Sea deltas. Palaeogeography, Palaeoclimatology, Palaeoecology, 95: 111-134.

Nagy, J. \& Basov, V.A. 1998. Revised foraminiferal taxa and biostratigraphy of Bathonian to Ryazanian deposits in Spitsbergen. Micropaleontology, 44: 217-255.

Nicoll, R.S. \& Foster, C.B. 1998. Revised biostratigraphic (Conodont Palynomorph) zonation of the Triassic of Western and Northwestern Australia and Timor. In: Purcell, P.G. \& Purcell, R.R. (Eds), The Sedimentary Basins of Western Australia 2: Proceedings of Petroleum Exploration Society of Australia Symposium, Perth, 1998: $129-139$.

Nicora, A. \& Premoli-Silva, I. 1976. Benthonic foraminifera of EarlyMiddle Triassic pelitic sequences from Chios (Greece) and Bithynia (Turkey) and correlations with conodont and ammonoid assemblages (preliminary note). In: Schafer, C.T. \& Pelletier, B.R. (Eds), First International Symposium on Benthic Foraminifera of Continental Margins. Part B, Paleoecology and Biostratigraphy. Maritime Sediments Special Publication, 1: 487-500.

Norling, E. 1968. On Liassic nodosariid foraminifera and their wall structures. Arrsbok Sveriges Geologiska Undersökning 61(8): Ser. C, 623: $1-75$.

Oberhauser, R. 1960. Foraminiferen und Mikrofossilien 'incertae sedis' der Ladinischen und Karnischen Stufe der Trias aus den Ostalpen und aus Persien. Geologischen Bundesanstalt, Jahrbuch, Wien, spec. v. 5: $5-46$.

Ogg, J.G. \& von Rad, U. 1994. The Triassic of the Thakkhola (Nepal). II: Paleolatitudes and Comparison with other Eastern Tethyan Margins of Gondwana. Geologisch Rundschau, 83: 107-129.

Oraveczné Scheffer, A. 1968. The representatives of the superfamily Miliolacea (Foraminifera) in the Carnian deposits, Borehole Bakonyszücs-1, Transdanubia, Hungary. A Magyar Allami Földtani Intezet: Evi Jelentése az 1968, Evröl (Annual Report of the Hungarian Geological Institute for 1968): 89-105.

Palmieri, V. 1994. Permian Foraminifera in the Bowen Basin, Queensland. Queensland Geology, 6: 1-126.

Parr, W.J. 1942. Foraminifera and a tubiculous worm from the Permian of the North-West Division of Western Australia. Journal of the Royal Society of Western Australia, Perth, 27: 97-115.

Parry, J.C., In Jones, D.K. 1967. Onslow No. 1 well, Western Australia, Well Completion Report. West Australian Petroleum Pty Ltd report (unpublished open file report).

Piller, W.E. 1983. Remarks on the suborder Involutinina Hohenegger and Piller, 1977. Journal of Foraminiferal Research, 13(3): 191-200.

Quilty, P.G. 1981. Early Jurassic foraminifera from the Exmouth Plateau, Western Australia. Journal of Paleontology, 55: 985-995.

Ramsay, D.C. \& Exon, N.F. 1994. Structure and tectonic history of the northern Exmouth Plateau and Rowley Terrace: outer North West Shelf. AGSO Journal of Australian Geology \& Geophysics (Canberra), 15(1): $55-70$ 
Sellier de Civrieux, J.M. \& Dessauvagie, T.F.J. 1965. Reclassification de quelques Nodosariidae, particulièrement du Permien au Lias. Publications de l'Institut d'Études et de Recherches Minières de Turquie, 124: $1-178$.

Stelck, C.R. 1975. The Albian Miliammina manitobensis zone in northeastern British Columbia. The Geological Association of Canada Special Paper, 13: 253-275.

Stelck, C.R. 1991. Foraminifera of the middle to upper Albian transition (Lower Cretaceous), northeastern British Columbia. Canadian Journal of Earth Sciences, 28(4): 561-580.

Stelck, C.R. \& Koke, K.R. 1987. Foraminiferal zonation of the Viking interval in the Hasler Shale (Albian), northeastern British Columbia. Canadian Journal of Earth Sciences, 24(11): 2254-2278.

Stelck, C.R. \& Leckie, D. 1988. Foraminiferal inventory and lithologic description of the Lower Cretaceous (Albian) Hulcross Shale, Monkman area, northeastern British Columbia. Canadian Journal of Earth Sciences, 25: 793-798.

Stelck, C.R. \& Leckie, D.A. 1990. Biostratigraphy of the Albian Paddy Member (Lower Cretaceous Peace River Formation), Goodfare, Alberta. Canadian Journal of Earth Sciences, 27: 1159-1169.

Strong, C.P. 1984. Triassic Foraminifera from Southland Syncline, New Zealand. New Zealand Geological Survey Paleontological Bulletin, 52: $1-62$.

Styk, O. 1975. Foraminifera from the Lower and Middle Triassic of Poland. Acta Palaeontologica Polonica, 20(4): 501-534.

Tappan, H. 1951a. Northern Alaska index foraminifera. Contributions from the Cushman Foundation for Foraminiferal Research, 2: 1-8.
Tappan, H. 1951b. Foraminifera from the Arctic Slope of Alaska. General Introduction and Part 1, Triassic Foraminifera. U.S. Geological Survey Professional Paper, 236A, US Government Printing Office. Washington, 1-20.

Tappan, H. 1955. Foraminifera from the Arctic slope of Alaska: Part 2 - Jurassic foraminifera. U.S. Geological Survey Professional Paper, 236B, US Government Printing Office. Washington, 21-90.

Taylor, D.J. 1964. Foraminifera and the stratigraphy of the western Victoria Cretaceous sediments. Proceedings of the Royal Society of Victoria, 77: 535-602.

Terquem, O. 1866. Cinquième mémoire sur les foraminifères du Lias des Départements de la Moselle, de la Côte-d'Or et de l'Indre. Metz: Lorette, éditeur-Libraire, 313-454.

Wall, J.H. 1960. Upper Cretaceous foraminifera from the Smoky River Area, Alberta. Research Council of Alberta, Bulletin, 6: $1-41$.

Zaninetti, L. 1969. Agathamminoides gen.n., un nouveau genre des Foraminifères du Trias alpin. Rivista Italiana Paleontologia $e$ Stratigrafia, 75(4): 697-704

Zaninetti, L. 1976. Les foraminifères du Trias. Rivista Italiana Paleontologia e Stratigrafia, 82(1): 1-258.

Zaninetti, L. 1979. Gsollbergella, new name for the foraminiferal genus Agathamminoides Zaninetti, 1969. Notes du Laboratoire de Paléontologie de L'Université de Genève, 3: 205-207.

Zaninetti, L. \& Whittaker, J.E. 1980. New records of Triassic foraminifera from the Shan States, Eastern Burma. Notes du Laboratoire de Paléontologie de L'Université de Genève, 6/2: 29-35. 